\title{
Microfinance and Ethnic Diversity
}

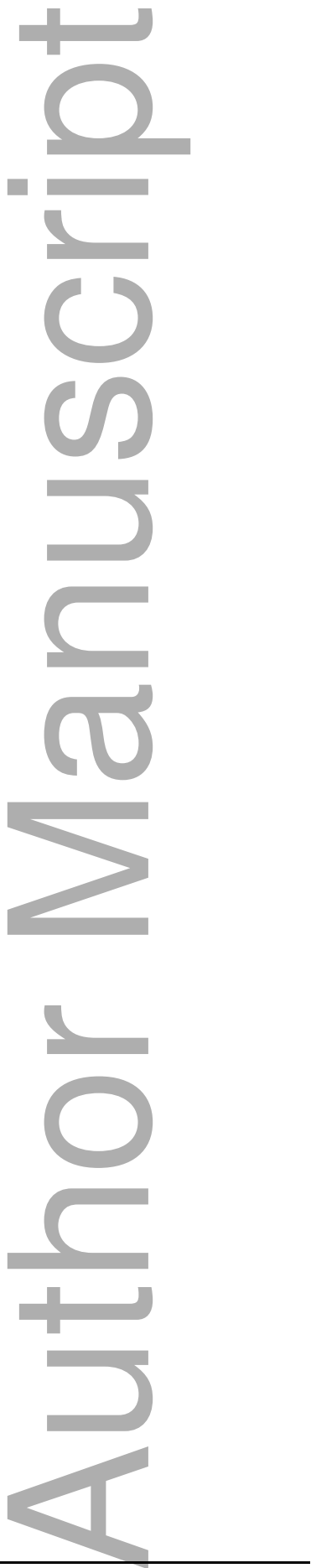

\author{
Sefa Awaworyi Churchill ${ }^{1}$ \\ Department of Economics \\ Monash University \\ Wellington Road, Clayton \\ VIC 3800, Australia
}

Email: sefa.awaworvi@monash.edu

\footnotetext{
${ }^{1}$ I am grateful to Russell Smyth and Vinod Mishra for comments on earlier draft of this paper. Thanks are also due to Mohit Agrawal, Klaus Ackerman, John Inekwe, seminar attendants at Monash University and two anonymous referees for useful comments on earlier drafts.

This is the author manuscript accepted for publication and has undergone full peer review but has not been through the copyediting, typesetting, pagination and proofreading process, which may lead to differences between this version and the Version of Record. Please cite this article as doi: $10.1111 / 1475-4932.12310$
}

This article is protected by copyright. All rights reserved 
Received Date : 12-Mar-2016

Revised Date : 08-Oct-2016

Accepted Date : 20-Oct-2016

Article type : Original Research

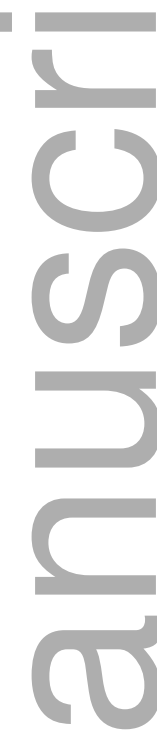

\title{
Microfinance and Ethnic Diversity
}

\begin{abstract}
We argue that understanding why the levels of success vary across microfinance institutions (MFIs) requires not only an understanding of the interplay between MFIs, MFI-specific practices and macroeconomic factors, but also what role ethnic diversity plays. Thus, this study hypothesizes a relationship between ethnic diversity and MFI performance. We measure ethnic diversity using indices of fractionalization. We find that fractionalization is associated with poorer MFI financial performance and leads to MFI mission drift. Trust and strong social networks are important mechanisms of influence; they are lower in more fractionalized countries. Results are robust to several sensitivity checks.
\end{abstract}

Keywords: Microfinance; Diversity; Ethnic; Religion; Linguistic; Fractionalization JEL Codes: G21; J15; L26; M13; Z12; L26

This article is protected by copyright. All rights reserved 


\section{Introduction}

The growing microfinance industry seeks to alleviate poverty through the provision of various financial services, particularly the provision of loans to the poor for the promotion of microenterprises (Yunus, 2003, 2008). The success of the industry, however, is not homogenous across microfinance institutions (MFIs) as some fail while others thrive and serve millions of clients (Awaworyi Churchill \& Nuhu, 2016). As a result, a growing literature focuses on discovering what makes microfinance flourish. A vast majority of the literature attempts to explain MFI performance by examining institution-specific practices, such as regulatory and profit status of MFIs, as well as managerial structures and decisions taken by MFI management (see, e.g., Arun \& Annim, 2010; Christen \& Drake, 2002; Hartarska, 2005; Hartarska \& Nadolnyak, 2007; Rosenberg et al., 2009). Another strand of the literature focuses on how the performance of MFls depends on macroeconomic and institutional factors (see, e.g., Ahlin \& Lin, 2006; Ahlin et al., 2011; Imai et al., 2012).

An issue that has not been studied is whether, and how, microfinance performance depends on ethnic and religious differences. Specifically, do ethnic and religious differences have any implications for microfinance performance? Are MFls affected by the level of racial and religious diversity in the country, or region, in which they operate? Is this relationship, if any, characterized by performance-enhancing effects or performance-retarding effects for MFIs? Put differently, are MFIs more, or less, likely to be effective if they operate in regions, or countries, with higher levels of racial and religious diversity? The focus of this study lies in answering these questions.

Ethnic and religious diversity could lead to an increase in the talent pool of a region and therefore increase the quality of local entrepreneurs (Fafchamps, 2000). In this regard, ethnic and religious heterogeneity could be favourable for MFls by presenting them with a wide range of promising entrepreneurs to fund. In other words, ethnic and religious diversity could lead to variations in economic and entrepreneurial activities within a country or region that favour MFIs and other credit allocation bodies. On the other hand, ethnic and religious heterogeneity can be associated with inequality among groups. In this regard, as a population becomes more diverse, inequalities (socioeconomic and otherwise) become greater. This can ignite animosity between groups, especially towards more prosperous groups (see, e.g., Himbara, 1994; Marris, 1971). These tensions 
could serve as disincentives for investment, ${ }^{1}$ and provide MFIs with unfavourable working environments.

Additionally, it is well known that microfinance institutions have a preference for individuals with specific socio-economic standing (e.g. occupation). Specifically, it is not uncommon for an MFI to publicly declare a preference for clients with a specific occupation. For instance, the ACP/EU MICROSAVE project in parts of Africa has, as part of its social goal, to provide cheap funds to farmers to help them thrive in their occupation. Consequently, with the dominance of certain occupations by certain ethnic groups, some MFIs appear to give special treatment to particular groups. On the other hand, for fear of being labelled as ethnic biased, some MFIs attempt to present a 'fair' distribution of their services and products to society, and therefore an increase in ethnic diversity might result in MFIs altering service provision strategies in their operations. By this line of reasoning, increased ethnic and religious diversity (fractionalization) would have some implications for MFI operations and performance. This is particularly true given that various ethnic and religious groups have been associated with specific occupations. This phenomenon could be explained by the notion of 'ethnic entrepreneurship', in which some ethnic groups have an inclination towards particular trades (Bogan \& Darity, 2008), perhaps because they are geographically placed where such trades thrive, cultural norms propel them into such trades or they have built up human capital through learning by doing that is passed on to successive generations from a very young age.

Thus, for some MFIs, although ethnicity and religion are not criteria for the determination of potential clients or loan issuance, in more ways than one, diversities reappear as very salient criteria, especially when MFIs target certain occupations or perhaps decide to operate from specific regions in a country. Furthermore, diversity may be connected to some level of economic exclusion, which further promotes prejudice against some groups, and hence reinforces the existing boundaries that microfinance seeks to overcome. In this regard, the association between microfinance and ethnic and religious diversity may put the industry at risk of becoming the service provider of a minority group within the poor community, by creating a system that relegates the needs of certain borrowers. This consequently defeats the social objective of reaching out to the poor as a whole.

Understanding the impact of ethnic and religious diversity on MFIs would help donors and policy makers understand the context within which microfinance thrives. It is important to know if microfinance would thrive in an ethnically and religiously fractionalized environment, and whether fractionalization affects the differences in performance of MFIs. For instance, the Grameen Bank of

\footnotetext{
${ }^{1}$ Prospective borrowers may restrain from investing in micro-enterprises as they may be afraid of what other groups may do. For instance, historic looting of ethnic Chinese shops in Indonesia could present significant fear amongst ethnic Chinese in the area and reduce their future investment.
}

This article is protected by copyright. All rights reserved 
Bangladesh is argued to be a pioneer of the group-lending model, and has been successful in using this model (see, e.g., Armendariz de Aghion \& Gollier, 2000; Stiglitz, 1990). The apparent success of the Grameen Bank in using this model inspired several governments and NGOs to establish grouplending schemes. Thus, for the purpose of replication, funding and evaluation, the Grameen Bank is often compared with other MFIs. However, evidence suggests that the group-lending scheme has not been successful in Thailand (Coleman, 1999). From the ethnolinguistic dataset of Alesina et al., (2003), ethnic fractionalization for Bangladesh is 0.05 whereas for Thailand, it is 0.63 . It might be that the success of Grameen Bank is due to low ethnic diversity in Bangladesh, characterised by higher levels of trust, which, a priori, is necessary for group lending to be effective. Conversely, it could be that the performance of MFIs in Thailand may be different if they operated in a less ethnically diverse country.

This study examines the hypothesis that cross-country differences in ethnic and religious diversity explain a substantial part of the cross-country differences in MFI performance. We explore and seek a better understanding of MFI performance by examining the direct effects of fractionalization on a wide range of MFI performance indicators. Given that MFIs claim to have a dual mission of reaching out to poor clients (social goal) and remaining financially viable (sustainability goal), we examine the impact of fractionalization along dimensions of both profitability and outreach depth (mission drift). For all social-driven banks, mission drift is a major concern. Mission drift occurs when there is a shift in the composition of new clients from poorer to wealthier clients (Cull et al., 2007).

Our main measures of ethnic and religious diversity are drawn from Alesina and Zhuravskaya (2011). This dataset provides indices of ethnic, linguistic and religious fractionalization at the regional (subnational) and national levels. The index of fractionalization captures the probability that two randomly selected individuals in a country/region belong to different ethnic/linguistic/religious groups. We relate indices of fractionalization to measures of MFI financial performance such as operational self-sufficiency (OSS), return on assets (ROA) and profit margin, and to measures of mission drift (depth of outreach) such as average loan size and share of female borrowers. We find that MFIs in more fractionalized countries perform poorly both financially and in terms of outreach depth. Specifically, an increase in fractionalization is associated with lower profitability across our measures of profitability. Further, fractionalization leads to a decline in the share of female borrowers, and an increase in the average loan size of MFIs, thus suggesting mission drift. We further investigate channels that may explain the effect of fractionalization on MFI performance. Specifically, we examine trust, social networks and discrimination among others as potential 
channels. We find evidence to suggest that the strength of social networks and trust is lower in more fractionalized countries, and this affects group lending and, subsequently, MFI outreach.

We contribute to the literature in several ways. First, this is the first study to examine the relationship between fractionalization and MFI performance. We document the effect of ethnic diversity on MFI performance. Understanding this relationship is important, as it presents a new perspective on the existing debate that seeks to understand why the levels of success vary across MFIs (see, e.g., Ahlin et al., 2011; Arun \& Annim, 2010; Christen \& Drake, 2002; Hartarska, 2005; Hartarska \& Nadolnyak, 2007; Rosenberg et al., 2009). Second, given that MFIs are compared for the purposes of funding, evaluation, and replication, this study presents a clearer basis on which MFI performance (success or failure) can be examined alongside institution-specific and macroeconomic factors. In comparing the performance of MFIs, existing trends show that factors mainly considered are MFI-specific factors and practices (see, e.g., Robinson, 2004). However, with the evidence presented in this study, we show that besides MFI-specific factors, country characteristics such as ethnic fractionalization levels explain differences in MFI performance across countries, and thus diversity should be a factor of interest when evaluating the performance of MFIs. Third, findings from this study can inform MFIs in their operations to determine appropriate strategies. Particularly, as MFIs perform poorly in highly fractionalized areas, our study provides a basis for MFIs to strategize accordingly when operating in highly fractionalized areas, or perhaps consider the implications of fractionalization in their operations. Lastly, the results from this study could guide policy makers, donors and investors in understanding the environment in which MFIs perform, and accordingly, help them tailor investments and donations.

\section{Why Should Ethnic Diversity Affect MFI Performance?}

The study of ethnic and religious diversity has a long history in both the economic and sociology literature. More so, the implications of ethnic and religious diversity seem widespread. In economics, cross-country work has examined the effects of ethnolinguistic fractionalization on poor politicoeconomic performance, growth, bureaucratic quality and governance quality (see, e.g., Alesina \& Zhuravskaya, 2011; Easterly \& Levine, 1997; Mauro, 1995). The focus of this study narrows our interest to the literature that exists on ethnic diversity and its association with credit and entrepreneurship.

The link between microfinance and entrepreneurship appears to be obvious as MFIs are considered a major credit allocation body for the development of micro-enterprises. While a large literature exists on the association between ethnicity and entrepreneurship, no study exists on whether, or 
how, ethnic diversity affects microfinance performance. In this section, we provide an overview of the conceptual arguments linking ethnic diversity to entrepreneurship and further argue why ethnic diversity would affect MFI performance.

It has been argued that cultural values influence the performance of business in various areas (Hofstede, 1984), and thus this influence explains why differential economic outcomes can be observed across different ethnic groups (Sowell, 1981). For instance, ethnic groups are endowed with different social and cultural institutions that can foster entrepreneurial talent at different levels (see, e.g., Ibrahim \& Galt, 2011; Wilson \& Portes, 1980). This explains why different ethnic groups dominate various trades, and also points to why differences in cultural values influence business performance. Accordingly, Lavoie (1991) argues that entrepreneurship takes place within culture, and it is utterly shaped by culture. This interplay between ethnicity, culture and entrepreneurship is further explained by various theories of ethnicity and entrepreneurship, such as ethnic enclave theory (see, e.g., Wilson \& Portes, 1980), middleman theory (see, e.g., Blalock, 1967; Bonacich, 1973; Aldrich \& Waldinger, 1990), and the theory of social capital (see, e.g., Ibrahim \& Galt, 2011).

Ethnic enclave refers to an area with a high concentration of co-ethnics characterized by a cultural identity and peculiar economic activity. The theory of ethnic enclave suggests that ethnic networks stimulate social connections, which generate a pool of resources that help promote entrepreneurship. This, to an extent, ties in with theories of social capital. These theories suggest that several resources (called social capital) are embedded in entrepreneurs' personal networks, and these resources enable them to identify new business opportunities and share information (see, e.g., Batjargal, 2003; Bhagavatula et al., 2010; Stam et al., 2014). The theory of middleman minorities suggests that cultural trends propel some ethnic groups to engage in specific trades which have to do with 'market intermediation'. ${ }^{2}$ Thus, our first argument for why we expect ethnic diversity to be associated with microfinance is that ethnic diversity is considered a core component of entrepreneurship and is therefore a factor to consider in examining the success of major credit allocation bodies such as MFIs.

Conceptually, there are several ways that ethnic and religious diversity could influence entrepreneurship and credit allocation. For instance, discrimination on the basis of taste (see, e.g., Akerlof, 1985; Becker, 1957), communication gaps across cultural boundaries (see, e.g., Cornell \& Welch, 1996; Loury, 1998), and social network effects (see, e.g., Montgomery, 1991; Taylor, 2000) may influence the allocation of credit and businesses in the long run.

\footnotetext{
${ }^{2}$ For instance, the Asians in East Africa, Jews in Europe and Syrians in West Africa (Bonacich, 1973).
} 
Becker (1957) argues that firms that discriminate would be forced out of business by more openminded businesses, as prejudice and discrimination could result in lower profits. ${ }^{3}$ Discrimination in credit allocation could emerge in various ways. For instance, as discussed earlier, some MFIs tend to target specific ethnic groups because of their preference for specific trades. Consistent with Becker's arguments, MFIs might suffer adverse consequences, especially with regards to loan repayments, when, due to discrimination, they fail to finance more productive trades or entrepreneurs. Subsequently, such MFIs may be forced out of operation when they become unsustainable financially due to substantial loan defaults. We therefore hypothesize that ethnic diversity leads to some level of discrimination in the selection of MFI clients, and this has implications for MFI profitability and outreach.

The social network effect has significant implications for MFIs, especially in the context of group lending and village banking. With the emergence of group lending, borrowers tend to identify themselves with certain groups, and subsequently apply for loans on the basis of being members of these groups. Karlan (2005) presents evidence that suggests cultural similarity tends to be a factor that draws group members to each other, and more homogenous (culturally similar) groups tend to exhibit lower defaults rates. Fractionalization could be a social boundary that leads to socioeconomic differences among potential clients and thus can be considered a hindrance in the selection of group members for micro-loans. Consequently, with an increase in fractionalization, it is likely that MFI outreach would be affected as group formation towards group-lending is substantially affected. This may lead to a reduction in the number of borrowers, as individuals might find it difficult to identify with each other culturally. Following Esteban and Ray (2008), we explain this mechanism further in the context of the definition of fractionalization and its relevant properties.

We can think of MFI outreach as a function of a vector of factors $\boldsymbol{X}$ and the level of difficulty in forming groups, say $D$, and all things equal, if $D$ increases, outreach decreases. This can be expressed as;

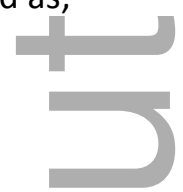

$$
\text { Outreach } \equiv f(\boldsymbol{X}, D)
$$

In the context of this study, difficulty in forming groups, $D$ is proxied by fractionalization, and thus we argue that as fractionalization increases, the level of difficulty in group formation increases, which negatively affects outreach. The index of fractionalization used in this study captures the probability that two randomly selected individuals in a country belong to different ethnic groups. It is computed using the Herfindhal Index.

\footnotetext{
${ }^{3}$ Becker (1957) introduced the first model of economic discrimination and theoretically examines the dynamics of discrimination, firm productivity and profits.
} 
Fractionalization $F$ is defined as follows:

$$
F=\sum_{i}^{k} n_{i}\left(1-n_{i}\right)=1-\sum_{i}^{k} n_{i}^{2}
$$

Here, $n_{i}$ is the share of population belonging to group $i$, where $i=1,2,3 \ldots k$ and $\sum_{i}^{k} n_{i}=1$. Relevant properties of $F$ are as follows; 1 ) $F$ is strictly quasi-concave with respect to $n_{i}, 2$ ) any transfer from a group to a smaller group may increase the value of $F$, and 3 ) the split of any group with population share $n_{i}$ into several new groups (for example $n_{i 1}, n_{i 2}, \ldots n_{i L}$ ) will increase the value of $F$.

In general, MFIs provide small loans to poor borrowers on the basis of group lending, which is often associated with joint liability. If the number of ethnic groups $(k)$ is sufficiently large such that each group consists of only one member, then $F$ will take a higher value (this follows from property 3 above). This also implies that an individual group will be very different from each other, which could be a potential source of conflict among groups (Esteban \& Ray, 2008). Hence group lending mechanism become difficult to implement. Thus, with higher values of $F$, there would be lower performance of MFIs.

Along these lines, Baycan-Levent et al. (2003) argue that the existence of social and ethnic networks motivate people to become entrepreneurs. This usually starts with the desire to design products that focus on attending to the needs of people in their own ethnic group. The in-group loyalty and trust provides a protected market and labour force that often presents the need for expansion. These networks are also characterized by privileged information about market opportunities. The basic idea is that information about opportunities circulates more effectively along interpersonal and social networks. In this context, more accurate information is associated with individuals or firms (such as MFIs) with better networks, and this allows them to pursue better market opportunities and/or better screen credit recipients or employees. A strand of the existing literature has shown that in the world of imperfect information, these processes provide economic advantages to agents (i.e., individuals or firms) that are better connected (see, e.g., Fafchamps, 1998; Kranton, 1996; Taylor, 2000).

Furthermore, in the context of MFI group lending, it is likely that individuals who do not have any social networks may be excluded. In essence, individuals without social networks may become victims of discrimination (Fafchamps, 2000), and this could affect the allocation of credit to such individuals. Social networks, however, are largely dependent on trust, and trust is lower in ethnically heterogeneous communities (see, e.g., Leigh, 2006; Alesina and Zhuravskaya, 2011). We therefore 
hypothesize that ethnic diversity affects social networks (and group lending), and thus affects MFI performance, especially outreach performance.

Conversely, in some cases, exclusion is not as a result of either discrimination or poor social networks. Due to various ethnic or religious influences, some groups or individuals belonging to certain groups cannot, or choose not to, borrow (Ledgerwood, 1999). Consequently, there are ethnically or religiously defined groups that remain unserved or underserved by MFIs. Furthermore, communication gaps as a result of fractionalization can be unfavourable to both MFIs and potential clients. If serious communication gaps exist, MFIs may not be able to communicate effectively with their clients, and this can make financial services to such clients more costly.

In the broader framework of entrepreneurship, both economists and sociologists have emphasized that ethnic and religious diversity has significant implications for enterprise start-up and success. Self-employment and business ownership is often higher among some ethnic groups than others (Smallbone et al., 2010). Similarly, investors are often attracted to particular regions because of their preference to work with specific ethnic or religious groups. For instance, it has been argued that due to the preference to deal with Muslims, coastal merchants penetrated East Africa rather than other parts of Africa (see, e.g., Ensminger, 1996; Fafchamps, 2000; Shillington, 2012). Likewise, the sociology literature has shown that some entrepreneurs prefer to do business with members of their own ethnic groups (see, e.g., Himbara, 1994; Marris, 1971), and others prefer to operate within environments characterized by ethnic diversity (see, e.g., Khayesi et al., 2004; Marris, 1971). Thus, ethnic diversity could determine the density of new businesses that may emerge in an area or potential businesses that need funding, and this influences MFI lending opportunities.

Overall, our main chain of logic is embedded in the arguments that the interplay between diversity, credit allocation and entrepreneurship has implications for MFI performance. This relationship has not received attention in the existing literature, and the aim of this study is to begin to fill the gap. The preceding discussions thus highlight important channels through which ethnic diversity might affect entrepreneurship. Based on these conceptualizations, we expect that:

Hypothesis 1 (H1): Ethnic diversity will negatively affect MFI performance via its effect on discrimination.

Hypothesis 2 (H2): Ethnic diversity will negatively affect MFI performance via its effect on trust.

Hypothesis 3 (H3): Ethnic diversity will negatively affect MFI performance via its effect on social networks. 


\section{Data}

This study pools together data from several different sources. The three main sources are discussed here. ${ }^{4}$ Microfinance related data is collected from the microfinance information exchange (MIX) market. Data on macroeconomic variables is collected from the World Bank's database of development indicators. Fractionalization data is drawn from Alesina and Zhuravskaya (2011).

Alesina and Zhuravskaya (2011) construct indices with ethnic, linguistic and religious compositions for a cross section of countries. The dataset provides observations at the national level, and also at the regional (sub-national) level. Owing to data availability issues, the indices computed for the cross-section of countries are not for the same years. Based on data availability, information is drawn from the census closest to the year 2000, and used in the computation of indices. This does not pose significant problems, as it is unlikely that the ethnic and religious composition of a country would change over a short period of time. For microfinance and macroeconomic variables, we take the mean value for each country for the five-year period 2000 to 2004 , and merge with the data on fractionalization. To ensure that our results are robust to the choice of years, we also run robust checks for averages for the years 2005 to 2009, and for the first and last years in our main specification (i.e., 2000 and 2004, respectively).

The ethnic and religious diversity data pools together information on the total population and the fraction of the population that belongs to a particular ethnic, linguistic or religious group in each region of the countries in the cross-section. This information is used to calculate indices of ethnic, linguistic and religious fractionalization at the regional level. Regional level data is also aggregated to the national level, and used in the construction of fractionalization indices at the national level. The fractionalization indices capture the probability that two randomly selected individuals in a country (or region) belong to different groups (ethnic, linguistic or religious). For details about the index construction process, see Alesina and Zhuravskaya (2011).

Consistent with the existing literature, our measures of mission drift include average loan size and percentage of female borrowers. Given that poorer clients usually demand smaller loans, an increase in MFI average loan size would reflect mission drift. Of course, as MFI clients mature and are successful in their businesses, it is likely that their demand for bigger loans would increase, and when this happens, average loan size may not necessarily capture mission drift. However, given that we are not able to capture the change in economic status of MFI clients, we consider the average loan size/GDP per capita (ALS) as a reliable measure of mission drift (see, e.g., Cull et al., 2007). We

\footnotetext{
${ }^{4}$ Other sources of data are discussed later as new variables are introduced in our analysis
} 
also consider the share of loans extended to women as a measure of mission drift. This is consistent with the existing literature, and is line with arguments that the most vulnerable in poor societies are women (see, e.g., Bhatt \& Shui-Yan, 2001; Cull et al., 2007). ${ }^{5}$

We also adopt measures of profitability consistent with the existing literature. Measures used in the existing literature include operational self-sufficiency (OSS), return on assets (ROA) and profit margin (see, e.g., Olivares-Polanco, 2005; Cull et al., 2007; Ahlin et al., 2011; Quayes, 2012). OSS is the ratio of financial revenue to the sum of operating expenses, impairment loss and financial expense. Profit margin is the ratio of the MFI's net operating income to its financial revenue. ROA is the ratio of the MFI's net operating income less taxes to the average total assets.

For regressions with the highest observations, our merged dataset contains 1275 MFIs, 306 subnational regions and 90 countries. Table 1 presents a summary of the most (and least) fractionalized countries with the number of MFIs in those countries. Table 2 presents summary statistics of variables used in regressions with highest observations. Figures 1, 2 and 3, respectively, present maps showing the degree of ethnic, linguistic and religious fractionalization across countries. Figure 4 shows the density of MFIs in each country.

\section{Model Specification and Methods}

Our primary goal is to establish whether fractionalization is associated with microfinance performance, conditional on the level of macroeconomic performance and MFI specific factors. To do this, we adopt a cross-section framework consistent with the existing literature (see, e.g., Awaworyi Churchill et al., 2015; Awaworyi Churchill, Valenzuela, \& Sablah, 2016; Easterly and Levine, 1997; Alesina et al., 2003). ${ }^{6}$ Thus, we run regressions of the following form;

$$
M F I_{j i}=\alpha+\beta F_{i}+\sigma^{\prime} \boldsymbol{X}_{i}+\delta^{\prime} \boldsymbol{M}_{j i}+\varepsilon_{j i}
$$

Here, MFI stands for microfinance performance indicators; F represents indices of fractionalization; $\boldsymbol{X}$ is a vector of country level covariates and $\boldsymbol{M}$ a vector of MFI level variables (discussed below), that are likely to affect microfinance performance. $\varepsilon$ is the error term and $j$ indexes an MFI $j$ located in country $i$

Our estimation technique is OLS with robust standard errors adjusted for heteroskedasticity. The OLS robust estimates account for heteroskedasticity and deal with observations that exhibit

\footnotetext{
${ }^{5}$ Share of loans extended to women also capture the extent to which female entrepreneurs are supported.

${ }^{6}$ Ahlin et al. (2011) use a similar specification to examine the impact of macroeconomic variables on MFI performance using panel data.
} 
relatively large residuals, influence, or leverage. For robustness, we further supplement OLS robust regressions with the two-staged least square (2SLS).

\subsection{Endogeneity}

If there are potential endogeneity issues, the use of OLS is not appropriate. In the context of our analysis, endogeneity may emerge if some underlying variables or factors, which are unobservable (i.e., cannot be quantified or recorded), are correlated with both fractionalization and our measures of MFI performance. It can be argued that there is a large literature that relates fractionalization to several political, economic and institutional factors, hence the potential of countless variables that may fit the description. Put differently, given the large body of literature that relates fractionalization to several political, economic, and institutional factors, there may be an issue regarding unobserved factors that may affect the interpretation of the correlation between fractionalization and MFI performance as causal.

The most common approach adopted to address endogeneity is an instrumental variable approach. We therefore adopt the 2SLS to examine the robustness of our results to endogeneity. The most commonly used instruments in the ethnic diversity literature include, variations in land quality, variations in elevation, latitude and duration of human settlement (see, e.g., Ahlerup \& Olsson, 2012; Collard \& Foley, 2002; Michalopoulos, 2012; Nettle, 1998; Wang and Steiner, 2015)

According to Michalopoulos (2012), exogenous variables, such as variations in land quality and elevation, largely inform the formation of ethnolinguistic diversity around the globe. They argue that a single ethnic identity is more likely to emerge with homogenous land qualities and elevations, whereas heterogeneous geographic conditions may result in more ethnic and linguistic diversity.

Michalopoulos discusses, various potential channels that can explain the link between geographic features and ethnic diversity. First, groups tend to form single ethnic identities along homogenous land endowments in order to enforce property rights and defend such endowments against intruders. With this logic, it is argued that groups that are more ethnically and linguistically similar are predisposed to settle around places with diverse land endowments. Second, geographic differences increase isolation between groups and can lead to a process of cultural drift, which, in the end, promotes the formation of distinct linguistic and cultural traits (Robert \& Richerson, 1985). Evidence presented by Michalopoulos (2012) suggests that geographic distances increase migration costs given that the physical distance between a pair of geographic areas decreases linguistic similarity. Also, heterogeneous geography encourages groups to accumulate skills specific to their 
local environment. Additionally, in situations in which production decisions are based on natural resources, such as land, people working on different types of land tend to acquire location-specific skills which are not easily transferable to other natural environments. Thus, geographic diversity increases isolation via the reduced mobility of people in a given area, and this leads to the formation of distinct cultural traits. This point is supported with the argument that ethnic groups are bearers of location-specific human capital.

Further to the insight by Michalopoulos (2012), another exogenous variable, country distance from the equator (latitude), has also being argued in the literature to be negatively correlated with ethnolinguistic diversity (Ahlerup and Olsson, 2012; Ashraf and Galor, 2013; Michalopoulos, 2012). Ahlerup and Olsson (2012) suggest that species richness or diversity ${ }^{7}$ emerges as a result of isolation and adaption. They argue that species richness increases with proximity to the equator, and variations in human skin colour comes partly from differences in UV radiations which are affected by latitude, altitude and humidity. In fact, evidence suggests that most of the variations in skin colour can be explained by natural variations in UV radiation, by latitude and also by altitude and precipitation (Chaplin, 2004). Races are often distinguished by skin colour. Thus, ethnic diversity is often linked with latitude.

The link between latitude and ethnic diversity is also explained by such factors as habitat diversity, climatic variability, and pathogen loads. It is argued that where climate is variable due to high latitude, individuals are compelled to use wider ecological niches, and the presence of high pathogen loads can, when local populations have adapted to them, be an isolating force by working both as barriers to their own movement outside the territory, and other populations' movement into the territory. This phenomenon, in the end, homogenizes populations ethnically and/or linguistically (Ahlerup \& Olsson, 2012; Collard \& Foley, 2002; Nettle, 1998).

Lastly, Ahlerup and Olsson (2012) argue that the exogenous variable, duration of human settlement, determines the formation of ethnolinguistic diversity around the globe. Ahlerup (2009) argues that the formation of ethnic groups takes considerable time and accordingly, longer durations of human settlement correspond with more time for ethnic group formation. Specifically, the duration of human settlement captures the historical duration of uninterrupted human settlements on a per country basis, and the dating is based on archeological research.

Our preferred instrument is the duration of human settlement since intuitively, we do not expect the duration of human settlement to affect microfinance performance directly. Thus, the exclusion

\footnotetext{
${ }^{7}$ Species richness refers to the number of different species represented in an ecological community, regions or landscape.
} 
restriction of using duration of human settlement is likely to hold since the main channel through which it can affect microfinance performance is ethnic diversity. On the other hand, for a geography based variable such as variations in land quality, although we do not expect a direct correlation with microfinance performance, an indirect link could be argued. For instance, soil and vegetation types in specific areas could influence occupations in such areas. Evidence suggests that populations living in areas with biogeography favourable for agriculture are inclined to develop dense farming populations (see, e.g., Olsson \& Hibbs, 2005). With various MFIs targeting certain groups with specific occupations such as farming, it can be argued that variations in land quality indirectly affects the choice of MFI clients and thus could affect outreach (and therefore financial performance as well). However, given the possibility of increased predictive power with more instrumental variables, we proceed to instrument ethnic diversity with duration of human settlement, variation in elevation and latitude ${ }^{8}$

\section{Results}

Regressions in Tables 3 to 5 present the results for the association between fractionalization and MFI profitability measures, namely, operational self-sufficiency (OSS), return on assets (ROA), and profit margin. Tables 6 and 7 present results for depth of outreach (mission drift) measures, namely, average loan size and percentage of female borrowers. In each of these tables, OLS results are presented in Panel A while 2SLS results are presented in Panel B. The measure of fractionalization in Columns 1 and 2 is ethnic fractionalization, Columns 3 and 4 is linguistic fractionalization, and Columns 5 and 6 is religious fractionalization.

First, we consider regressions in which our explanatory variable includes only the indices of fractionalization (odd columns in each table). Even Columns add a set of MFI-specific and macroeconomic determinants of MFI performance. Specifically, for MFI-specific factors, we control for the age and assets of MFIs, the gross loan portfolio, and also the profit status of MFIs. Assets and gross loan portfolio are used as covariates to control for MFI size. Dummies for for-profit MFIs are included to control for MFI type and institutional practices. For macroeconomic determinants of MFI performance, consistent with the existing literature (see, e.g., Ahlin \& Lin, 2006; Ahlin et al., 2011), we control for GDP per capita growth, share of private credit in GDP, remittances, population density, unemployment rate, and a measure of institutional quality.

\footnotetext{
${ }^{8}$ These instruments have been used in the existing literature to instrument fractionalization (see, e.g., Awaworyi Churchill et al., 2015; Awaworyi Churchill, 2016; Wang and Steiner, 2015). Data on latitude and variation elevation are taken directly from Michalopoulos (2012). Data on duration of human settlement are taken directly from Ahlerup and Olsson (2012).
} 
GDP per capita growth is a proxy for economic growth and has been hypothesized to affect MFI performance. For instance, high growth may be accompanied by better institutions (Acemoglu et al., 2005; Glaeser et al., 2004) that promote MFIs, and may also increase demand and provide new niches for microenterprises (Ahlin et al., 2011), which in the long run is good for MFI performance. Furthermore, Easterly and Levine (1997) find that fractionalization has an impact on GDP growth and thus by controlling for GDP growth, we attempt to isolate the direct causality of fractionalization on MFI performance. Share of private sector credit in GDP is a widely used measure of financial development, and therefore it is included in our specification to serve as a proxy for the financial depth of a country in which MFIs operate. Remittance is compensation of employees and workers' remittances received as a share of GDP. The unemployment rate reflects prevalence of labour opportunities and jobs in the economy and thus could potentially affect microfinance performance as they may inform entrepreneurial decisions. The population density variable is similarly important as it captures the size of countries in which MFIs operate and this may have a direct effect on MFI performance. We also control for institutional quality. Our measure of institutional quality is the average of the six indicators of institutional quality reported in the World Bank's World Governance Indicators (WGI) database. ${ }^{9}$ This single measure of institutional quality has previously been used in the existing literature (see, e.g., Easterly, 2007).

We also include the share of the main religions in the population (i.e., Muslim, Protestant, and Catholic) as well as regional dummies which reflect the geographic regions in which countries fall.

\subsection{Financial Performance and Fractionalization}

Quite robustly, we find that our indices of fractionalization are significantly associated with measures of profitability. These associations are mainly negative and are consistent across the various specification types. In what follows, we discuss coefficients for the regressions with the most complete specification. ${ }^{10}$ Based on OLS results, moving from complete ethnic homogeneity to complete heterogeneity is associated with a decrease in: OSS of 25 percentage points, ROA of 7 percentage points, and profit margin of 31 percentage points. A standard deviation increase in ethnic fractionalization is associated with a 0.15 standard deviation decrease in OSS, a 0.10 decrease in ROA, and a 0.09 decrease in profit margin. Thus, ethnic heterogeneity is negatively associated with MFI profitability, and this is consistent across all measures of profitability.

\footnotetext{
${ }^{9}$ The World Bank's governance indicators include government effectiveness, control of corruption, political stability, voice and accountability, rule of law and regulatory quality.

${ }^{10}$ That is regressions including all control variables. These are reported in even columns.
} 
With regards to linguistic fractionalization, a transition from complete linguistic homogeneity to complete heterogeneity is associated with a fall of 30 percentage points in OSS, 10 percentage points in ROA, and 26 percentage points in profit margin. A standard deviation increase in linguistic fractionalization is associated with a 0.18 standard deviation decrease in OSS, a 0.15 decrease in ROA, and a 0.08 decrease in profit margin. Thus, overall, there is evidence of a negative association between linguistic fractionalization and all measures of MFI profitability. However, turning to the effect of religious fractionalization, results show a statistically insignificant association between fractionalization and all three measures of profitability.

2SLS results also suggest a strong negative effect of fractionalization on MFI profitability, and unlike in the case of the OLS, 2SLS results are consistent across all measures of fractionalization. The Sargan-Hansen overidentifying restriction (OIR) tests and first-stage statistics are reported at the bottom of each table. First-stage results are consistent with the existing literature. Specifically, the positive signs on duration of human settlement and variation in elevation are consistent with Ahlerup and Olsson (2012) and Michalopoulos (2012), respectively, while the negative sign on latitude confirms Nettle's (1998) findings. Overall, we fail to reject the null hypothesis for the OIR tests, which supports the validity of our instruments and suggest that the three instruments we used for fractionalization were not overidentified in first-stage regressions. $F$-statistics further show that the instruments used are jointly significant in the regressions.

From Panel B, we observe that 2SLS estimates are mostly larger than those reported for OLS regressions. Furthermore, in some cases where OLS results were statistically insignificant, they appear significant in 2SLS results. For instance, we observe statistically insignificant effects of religious fractionalization on all measures of financial performance in the OLS. However, 2SLS results show that a standard deviation increase in religious fractionalization is associated with a 0.33 standard deviation decrease in ROA, and a 0.62 decrease in profit margin. Thus, overall, given the association between various fractionalization measures and MFI financial performance, we can conclude that OLS results understate the effects of fractionalization. Our conclusion of a negative effect of fractionalization on financial performance still holds, and more importantly, 2SLS results strengthen the main conclusions drawn from the OLS.

Based on 2SLS results, we observe a consistent trend in the results where the effects of linguistic fractionalization on measures of financial performance are stronger (i.e., standardized coefficients are quantitatively larger) than those of ethnic fractionalization. Similarly, the effects of religious fractionalization appears to be stronger than those of linguistic fractionalization. These variations, 
perhaps, could be as a result of the channels through which fractionalization affects MFI performance.

\subsection{Mission Drift and Fractionalization}

Turning to the effects of fractionalization on our measures of mission drift, we find that ethnic diversity increases the probability of mission drift occurring. Consistently, ethnic and religious fractionalization indices show a positive effect on ALS. From Panel A, OLS results show that a standard deviation increase in ethnic, linguistic and religious fractionalization, respectively, is associated with a standard deviation increase of $0.11,0.09$ and 0.25 in ALS. Thus, overall, we can conclude that moving from complete homogeneity to heterogeneity is associated with an increase in MFI ALS.

With regards to effects on share of female borrowers, we find consistent evidence of a negative association between all indices of fractionalization and the share of female borrowers. Here, a standard deviation increase in ethnic, linguistic, and religious fractionalization, respectively, is associated with a decrease of $0.16,0.17$, and 0.13 standard deviations in the share of female borrowers.

Comparing these results to 2 SLS results, we find that 2 SLS results are consistently larger than OLS results. Specifically, from Table 6 Panel B, 2SLS results show that a standard deviation increase in ethnic, linguistic and religious fractionalization, respectively, is associated with a standard deviation increase of $0.55,0.17$ and 0.30 in ALS. Also, from Table 7 Panel B, 2SLS results show that a standard deviation increase in ethnic, linguistic and religious fractionalization, respectively, is associated with a standard deviation increase of $0.23,0.62$ and 0.29 in the share of female borrowers. These results do not only confirm conclusions emerging from OLS regressions but they also reinforce these conclusions.

\subsection{Robust and sensitivity checks}

We conduct several exercises to verify the robustness of our results. Specifically, we examine the robustness of our results to different samples and alternative measures of fractionalization. Results for robustness checks are presented in the online appendix.

\section{Different sample}


We examine the effect of different samples on our results. To start with, given that our main results are based on the five-year period (2000 to 2004) of MFI observations, we consider individual years to see if our results are robust to the choice of years. We consider the start (2000) and end (2004) of the five-year period. We also consider the average of the next five-year period, 2005 to 2009. Results for this exercise are presented in the online appendix Tables A1 to A6. We also split our sample to capture MFI profit status. We report results for not-for-profit MFIs and for-profit MFIs (Tables A7 to A10) to examine if any observable variations may exist with this distinction.

Results from individual years $(2000,2004$, and 2005 to 2009 average) are identical to our main results. Considering our disaggregation by profit-status, results for the not-for-profit sample are identical to or main results. However, we note that profitability results from the for-profit sample are mainly statistically insignificant. Further, results show a positive effect of religious fractionalization on the OSS, which is inconsistent with our main results. With the for-profit sample (profitability regressions only) being the only exception, overall we can conclude that our results are robust to different samples.

The effect of fractionalization in the case of for-profit MFIs could be a result of their lending strategies. Generally, for-profit MFIs issue bigger loans (usually to individuals) as they are not socially driven. Put differently, given that it is relatively expensive and risky to serve poorer clients, for-profit MFIs usually serve wealthier clients who require individual loans rather than group loans. Furthermore, given that for-profit MFIs are profit driven, they are predisposed to choosing more productive entrepreneurs, and therefore they are not constrained by the objective of extending loans to clients engaged in specific trades. Thus, the effect of fractionalization on group lending may not have implications for for-profit MFIs, and where fractionalization holds significant implications, a positive effect is not unexpected. ${ }^{11}$

\section{Alternative measures of fractionalization}

We explore whether a similar relationship exists between MFI performance and alternative measures of fractionalization. We use two alternative measures of fractionalization: a regional (subnational) fractionalization index from Alesina and Zhuravskaya (2011) and a national level fractionalization index from Alesina et al. (2003). The widely used indices of fractionalization from Alesina et al. (2003) are constructed directly from national level census and observations. However, Alesina and Zhuravskaya (2011) first collect information at the regional (sub-national) level and then

\footnotetext{
${ }^{11}$ In line with Fafchamps(2000) who suggests that ethnic and religious diversity could lead to an increase in the talent pool of a region, and therefore increase the quality of local entrepreneurs, a positive effect of fractionalization on profitability could be expected for for-profit MFIs given their objectives and choice of clientele.
} 
aggregate this into national level indices. We determine the regions of operation of MFIs and match them with regional level indices from Alesina and Zhuravskaya (2011). Results for the effects of alternative measures of fractionalization are presented in Tables A11 to A14. Results suggest that the association between fractionalization and MFI performance is not altered by the index of fractionalization used. Thus, overall, effects of fractionalization on MFI performance are robust to alternative measures of fractionalization.

\section{Why Fractionalization is bad for MFI Performance}

Based on the results presented above, two major conclusions emerge: 1) fractionalization is negatively associated with MFI profitability, and 2) fractionalization causes mission drift or is bad for MFI outreach depth. Hence, overall, considering both measures of MFI performance, we can conclude that fractionalization is bad for MFI performance. Several different arguments suggest a negative relationship between fractionalization and good performance for MFIs. We discuss these arguments in this section by reviewing the potential channels through which fractionalization affects MFI performance. Consistent with our hypotheses discussed in Section 2, we examine trust, social network and discrimination as potential channels through which ethnic diversity affects microfinance performance.

\section{Trust}

The observed effect of fractionalization on MFI performance could be as a result of the 'trust effect'. Group formation towards MFI group lending is largely contingent on trust. Generally, individuals would prefer to form groups with others they know and trust. Furthermore, given the socioeconomic status of most MFI clients, formal collateral is not practical, and thus it is argued that credit allocation largely hinges on trust (Fafchamps, 1996, 1997). Furthermore, trust among individuals plays a major role in the success of business as the enabling environment for trade is built on trust (Granovetter, 1985; Milgrom et al., 1990; Mitchell, 1969; Platteau, 1994). Thus, in the absence of trust, social networks (and thus group formations) are hindered, credit allocation is affected and poor business environments emerge (Awaworyi Churchill, 2016). These are factors that negatively affect the performance of MFIs.

A vast literature suggests that ethnic and religious homogeneity are elements that promote trust (see, e.g., Cornell \& Welch, 1996; Fukuyama, 1995). Also, Glaeser (2005) suggests that heterogeneity may reinforce negative stereotypes, increase hate and therefore reduce trust between groups. Thus, with higher fractionalization, trust is reduced. 
Further, for trust and other factors to qualify as channels of influence, in addition to being related to fractionalization, they should also be related to MFI performance measures, and the inclusion of these measures as additional covariates in original cross-section regressions linking MFI performance to fractionalization should lead to a decrease in magnitude of the coefficient on fractionalization. Thus, following Alesina and Zhuravskaya (2011), we introduce a measure of generalized trust into our MFI performance regressions. Table 8 Panel A presents results for these regressions. To save space, for each regression, we only report the coefficient on fractionalization. Columns 1 to 3 report results on the effects of ethnic, linguistic and religious fractionalization, respectively, using the most complete specification including all control variables as reported in Tables 3 to 7.

We measure trust using data from the World Values Survey (WVS) that addresses the question: 'Generally speaking, would you say that most people can be trusted or that you cannot be too careful in dealing with people?' The index of trust generated takes the average percentage of respondents per country who give a positive answer (i.e., 'most people can be trusted'). Comparing results from Panel $A$ to those reported in Tables 3 to 7 , we find that although the number of observations reduces with the addition of trust as an additional covariate, the inclusion of this variable also reduces the size of the coefficient on fractionalization or renders it statistically insignificant. This suggests that trust is a potential channel that links fractionalization to MFI performance.

\section{Social Networks}

In line with Alesina and Ferrara (2000), we argue that individuals who live in heterogeneous communities are less likely to participate in social groups. This could be as a result of issues related to trust as discussed above. Specifically, social networks are dependent on trust (Awaworyi Churchill \& Mishra, 2016), but trust is lower in more heterogeneous communities. Conversely, it may be argued that an increase in fractionalization could imply the formation of more social groups as social groups could emanate from each ethnic group. But, membership in these groups would be relatively weak, and these relatively small heterogeneous groups, compared to their homogenous counterparts, tend to exhibit weaker in-group relationships (La Ferrara, 2002). In essence, the density and strength of social networks built under these circumstances are weak. Given that microfinance depends on strong social networks to flourish (Giné et al., 2010), a negative influence of fractionalization on the social network is detrimental to MFI performance.

To test social network as a potential channel, we measure social networks using the 'social groups' question from the WVS, namely, 'Are you an active member, an inactive member or not a member 
of a self-help group or mutual aid group?' The survey responses are coded from 0 to 2 , and we use the mean country scores as a measure of social network. ${ }^{12}$ We introduce this measure of social network into our MFI performance regressions. Results reported in Panel B of Table 8 suggest that social network is a potential channel that links fractionalization to MFI performance given that the inclusion of social network as an additional covariate either reduces the magnitude of coefficients or renders them statistically insignificant.

\section{Discrimination}

As mentioned earlier, discrimination can be costly for MFIs as it could result in lower profits (see, Becker, 1957). Discrimination could further determine which clients MFIs serve and thus might lead to the exclusion of several borrowers, perhaps the poorest. A possible implication for outreach is mission drift as MFIs drift away from their social mission of serving the poor. While fractionalization increases issues of discrimination (see, e.g., Awaworyi Churchill et al., 2016), it is possible that discrimination in itself could generate ethnic bias which affects the allocation of credit and entrepreneurial activities (Forbes et al., 2006; Masurel et al., 2004). In this regard, certain ethnic groups may have the economic advantage of benefiting from MFI loans, and where the benefiting ethnic groups are perhaps not the most effective (or innovative), MFIs may suffer some negative consequences

To test discrimination as a potential channel, we adopt a measure of discrimination consistent with the existing literature (see, e.g., Awaworyi Churchill et al., 2016). The WVS asks the question: 'When jobs are scarce, men should have more right to a job than a woman' Responses are scored from 1 to 3 , and the index of discrimination generated takes the average percentage of respondents per country who agree that men should have more rights. ${ }^{13}$ We introduce this measure of discrimination into our MFI performance regressions. Results are reported in Panel C of Table 8. These results are consistent with what we observe in the case of trust and social networks. We find that results mostly show a reduction in coefficient size or statistical insignificance of fractionalization compared to our main results reported in Tables 3 to 7 . This supports discrimination as a potential channel that links fractionalization to MFI performance.

\section{Summary and Conclusions}

This study analyses empirically the association between fractionalization and microfinance institution (MFI) performance. Ethnic, linguistic, and religious fractionalization indices are used as

\footnotetext{
${ }^{12} 0$ for not a member, 1 for inactive member and 2 for active member.

${ }^{13}$ The WVS originally scored 1 for agree, 2 for neither and 3 for disagree.
}

This article is protected by copyright. All rights reserved 
measures of diversity to examine the direct effects of diversity on MFI performance. In addition to examining the financial performance of MFIs in the context of fractionalization, we also examine whether a significant association exists between fractionalization and microfinance outreach performance (social goals). Two-staged least square (2SLS) results show detrimental effects of fractionalization indices on MFI performance. Specifically, for profitability, fractionalization is harmful to MFI operational self-sufficiency, return on assets, and profit margin. For outreach depth, results suggest that fractionalization leads to mission drift as higher fractionalization leads to a lower share of female borrowers and higher average loan size.

We investigate potential and interrelated channels behind this adverse effect. We find that fractionalization negatively affects the level of social capital, and thus affects structures that promote trust, and social and economic transactions. This adverse effect makes it difficult and more expensive to build and sustain financial intermediation systems such as MFIs. Group formation towards group lending is also affected and this affects the dynamics of loan issuance. Discrimination also emanates as a result of higher fractionalization and this affects credit allocation.

Beyond the contributions to the literature on the determinants of MFI performance and what influences the funding of entrepreneurs, our study also contributes to theories relating to institutional logics, social capital, ethnic enclaves, and ethnic entrepreneurship. Specifically, microfinance promotes ethnic entrepreneurship via the preference to serve individuals with specific socio-economic status (e.g., occupation). The preference to serve groups or individuals with specific occupations also explains the success of ethnic enclaves, characterized by a cultural identity and peculiar economic activity. Our contribution to the theory of social capital relates to the impact of fractionalization on microfinance via social networks and the relevance of social capital in promoting group lending and microfinance performance.

With regard to institutional theory, we find that ethnic diversity can reinforce issues relating to MFI mission drift. Thus, the displacement of the development logic by the banking logic in the existing literature (Battilana \& Dorado, 2010; Kent \& Dacin, 2013) could be explained by the effects of ethnic diversity which compels MFIs to move away from relatively poorer clients to richer clients. Microfinance research conducted by management theorists is relatively scant; however, the research that exists place microfinance in the context of institutional theory (see, e.g., Battilana \& Dorado, 2010; Kent \& Dacin, 2013; Khavul et al., 2013). Here, it is argued that MFIs attempt to combine two separate institutional logics in their operations: a development logic which guides MFIs in their social mission of reaching out to the poorest and a banking logic that supports the idea of financial viability. An extensive literature examines the difficulty in combining these two institutional 
logics (see, e.g., Battilana \& Dorado, 2010; Hermes \& Lensink, 2011; Hermes et al., 2011), and research has shown that, over time, tensions between logics reduce as one logic gains dominance over others (Selznick, 1949). Our findings show that ethnic diversity plays a significant role which allows the banking logic to dominate the development logic in MFI operations.

Given the findings from this study, it is evident that higher levels of fractionalization negatively influence social outcomes such as trust, networks, and discrimination, and this presents detrimental effects on MFI performance. While policy may not be able to directly control the level of fractionalization in an area, appropriate policy can help mitigate the negative effects of ethnic diversity. For instance, evidence from the sociology and psychology literature suggests that superordinate goals can be effective in promoting trust and reducing tensions among heterogeneous groups (see, e.g., Sherif, 1958). Thus, policymakers can adopt policies along these lines to help mitigate the negative effects of ethnic diversity in highly fractionalized areas.

Future research can consider the use of other impact assessment methods such as randomised control trials to examine the relationship between ethnic diversity and MFI performance.

\section{References}

Acemoglu, D., Johnson, S., \& Robinson, J. A. (2005). Institutions as a fundamental cause of long-run growth. Handbook of Economic Growth, 1, 385-472.

Ahlerup, P., \& Olsson, O. (2012). The roots of ethnic diversity. Journal of Economic Growth, 17(2), 71102. doi: 10.1007/s10887-011-9075-0

Ahlin, C., \& Lin, J. (2006). Luck or Skill? MFI Performance in Macroeconomic Context. BREAD Working Paper No. 132.

Ahlin, C., Lin, J., \& Maio, M. (2011). Where does microfinance flourish? Microfinance institution performance in macroeconomic context. Journal of Development Economics Volume 95, Issue 2, 105-120.

Akerlof, G. A. (1985). Discriminatory, status-based wages among tradition-oriented, stochastically trading coconut producers. The Journal of Political Economy, 93(2), 265-276. 
Aldrich, H. E., \& Waldinger, R. (1990). Ethnicity and entrepreneurship. Annual Review of Sociology, $16,111-135$.

Alesina, A., Devleeschauwer, A., Easterly, W., Kurlat, S., \& Wacziarg, R. (2003). Fractionalization. Journal of Economic Growth, 8(2), 155-194.

Alesina, A., \& Ferrara, E. L. (2000). Participation in Heterogeneous Communities. The Quarterly Journal of Economics, 115(3), 847-904.

Alesina, A., \& Zhuravskaya, E. (2011). Segregation and the Quality of Government in a Cross Section of Countries. American Economic Review, 101(5), 1872-1911.

Armendariz de Aghion, B., \& Gollier, C. (2000). Peer Group Formation in an Adverse Selection Model The Economic Journal, 110(465), 632-643.

Armendáriz, B., \& Morduch, J. (2007). The Economics of Microfinance The Economics of Microfinance. Canmbrige: The MIT Press.

Arun, T. G., \& Annim, S. K. (2010). Economic Governance of MFIs: Inside the Black Box. Rochester.

Ashraf, Q., \& Galor, O. (2013). The 'Out of Africa' Hypothesis, Human Genetic Diversity, and Comparative Economic Development. American Economic Review, 103(1), 1-46. doi: 10.1257/aer.103.1.1

Awaworyi Churchill, S. (2016). Fractionalization, entrepreneurship, and the institutional environment for entrepreneurship. Small Business Economics, 1-21. doi: 10.1007/s11187-016-9796-8

Awaworyi Churchill, S., \& Mishra, V. (2016). Trust, Social Networks and Subjective Wellbeing in China. Social Indicators Research, 1-27.

Awaworyi Churchill, S., \& Nuhu, A. S. (2016). What has failed: microfinance or evaluation methods? Journal of Sustainable Finance \& Investment, 6(2), 85-94. doi:

10.1080/20430795.2016.1176424

Awaworyi Churchill, S., Ocloo, J. E., \& Siawor-Robertson, D. (2016). Ethnic Diversity and Health Outcomes. Social Indicators Research, 1-36. doi: 10.1007/s11205-016-1454-7

Awaworyi Churchill, S., Okai, D., \& Posso, A. (2015). Internet Use and Ethnic Heterogeneity in a Cross-Section of Countries. Economic Papers: A journal of applied economics and policy, 35(1), 59-72. doi: 10.1111/1759-3441.12125

Awaworyi Churchill, S., Valenzuela, M. R., \& Sablah, W. (2016). Ethnic diversity and firm performance: Evidence from China's materials and industrial sectors. Empirical Economics, 1-21. doi: 10.1007/s00181-016-1174-5

This article is protected by copyright. All rights reserved 
Batjargal, B. (2003). Social capital and entrepreneurial performance in Russia: A longitudinal study. Organization Studies, 24(4), 535-556.

Battilana, J., \& Dorado, S. (2010). Building sustainable hybrid organizations: the case of commercial microfinance organizations. Academy of Management journal, 53(6), 1419-1440.

Baycan-Levent, T., Gülümser, A., Kundak, S., Nijkamp, P., \& Sahin, M. (2003). Diversity and ethnic entrepreneurship: dialogue through exchanges in the economic arena. SusDiv Position Paper 4.4

Becker, G. S. (1957). The economics of discrimination. Chicago: University of Chicago press.

Bhagavatula, S., Elfring, T., van Tilburg, A., \& van de Bunt, G. G. (2010). How social and human capital influence opportunity recognition and resource mobilization in India's handloom industry. Journal of Business Venturing, 25(3), 245-260.

Bhatt, N., \& Shui-Yan, T. (2001). Making Microcredit Work in the United States: Social, Financial, and Administrative Dimensions. Economic Development Quarterly, 15(3), 229.

Blalock, H. (1967). Toward a theory of minority-group relations. New York: Capricorn Books.

Blau, F. D., Ferber, M. A., Winkler, A. E., \& Winkler, A. E. (1986). The economics of women, men, and work: Prentice-Hall Englewood Cliffs, NJ.

Bogan, V., \& Darity, W. (2008). Culture and entrepreneurship? African American and immigrant selfemployment in the United States. The Journal of Socio-Economics, 37(5), 1999-2019.

Bonacich, E. (1973). A Theory of Middleman Minorities. American Sociological Review, 38(5), 583594. doi: $10.2307 / 2094409$

Carr, J. C., Cole, M. S., Ring, J. K., \& Blettner, D. P. (2011). A measure of variations in internal social capital among family firms. Entrepreneurship Theory and Practice, 35(6), 1207-1227.

Chaplin, G. (2004). Geographic distribution of environmental factors influencing human skin coloration. American Journal of Physical Anthropology, 125(3), 292-302.

Christen, R., \& Drake, D. (2002). Commercialization. The new reality of microfinance. In D. Drake \& E. Rhyne (Eds.), The commercialization of microfinance. balancing business and development (pp. 2-22). Bloomfield: Kumarian Press.

Coleman, B. (1999). The impact of group lending in Northeast Thailand. Journal of Development Economics, 60, 105-141.

This article is protected by copyright. All rights reserved 
Collard, I. F., \& Foley, R. A. (2002). Latitudinal patterns and environmental determinants of recent human cultural diversity: do humans follow biogeographical rules? Evolutionary Ecology Research, 4(3), 371-383.

Cooper, A. C., Folta, T. B., \& Woo, C. (1995). Entrepreneurial information search. Journal of Business Venturing, 10(2), 107-120.

Cornell, B., \& Welch, I. (1996). Culture, information, and screening discrimination. Journal of Political Economy, 542-571.

Cull, R., Demirguc-Kunt, A., \& Morduch, J. (2007). Financial Performance and Outreach: A Global Analysis of Leading Microbanks. Economic Journal, 117(517), F107-133.

De Carolis, D. M., \& Saparito, P. (2006). Social capital, cognition, and entrepreneurial opportunities: A theoretical framework. Entrepreneurship Theory and Practice, 30(1), 41-56.

Easterly, W. (2007). Inequality does cause underdevelopment: Insights from a new instrument. Journal of Development Economics, 84(2), 755-776.

Easterly, W., \& Levine, R. (1997). Africa's growth tragedy: policies and ethnic divisions. The Quarterly Journal of Economics, 112(4), 1203-1250.

Ensminger, J. (1996). Making a market: The institutional transformation of an African society: Cambridge University Press.

Fafchamps, M. (1996). The enforcement of commercial contracts in Ghana. World Development, 24(3), 427-448.

Fafchamps, M. (1997). Trade credit in Zimbabwean manufacturing. World Development, 25(5), 795815

Fafchamps, M. (1998). Market emergence, trust and reputation: Department of Economics, Stanford University, Stanford.

Fafchamps, M. (2000). Ethnicity and credit in African manufacturing. Journal of Development Economics, 61(1), 205-235.

Forbes, D. P., Borchert, P. S., Zellmer-Bruhn, M. E., \& Sapienza, H. J. (2006). Entrepreneurial team formation: An exploration of new member addition. Entrepreneurship Theory and Practice, 30(2), 225-248.

Fukuyama, F. (1995). Trust: The social virtues and the creation of prosperity. New York: Free press. 
Gedajlovic, E., Honig, B., Moore, C. B., Payne, G. T., \& Wright, M. (2013). Social Capital and Entrepreneurship: A Schema and Research Agenda. Entrepreneurship Theory and Practice, 37(3), 455-478. doi: 10.1111/etap.12042

Ghatak, M., \& Guinnane, T. (1999). The Economics of Lending with Joint Liability: Theory and Practice. Journal of Development Economics, 60(1), 195-228.

Giné, X., Jakiela, P., Karlan, D., \& Morduch, J. (2010). Microfinance Games. American Economic Journal. Applied Economics, 2(3), 60-95.

Glaeser, E. L. (2005). The political economy of hatred. The Quarterly Journal of Economics, 45-86.

Glaeser, E. L., La Porta, R., Lopez-de-Silanes, F., \& Shleifer, A. (2004). Do institutions cause growth? Journal of Economic Growth, 9(3), 271-303.

Granovetter, M. (1985). Economic action and social structure: the problem of embeddedness. American Journal of Sociology, 91(3), 481-510.

Green, E. D. (2005). On the Endogeneity of Ethnic Secessionist Groups. PhD diss., London School of Economics.

Greve, A., \& Salaff, J. W. (2003). Social networks and entrepreneurship. Entrepreneurship Theory and Practice, 28(1), 1-22.

Hansen, E. L. (1995). Entrepreneurial networks and new organization growth. Entrepreneurship Theory and Practice, 19(4), 7-20.

Hartarska, V. (2005). Governance and performance of microfinance institutions in Central and Eastern Europe and the Newly Independent States. World Development, 33(10), 1627-1643.

Hartarska, V., \& Nadolnyak, D. (2007). Do regulated microfinance institutions achieve better sustainability and outreach? Cross-country evidence. Applied Economics, 39(10), 1207-1222.

Hermes, N., \& Lensink, R. (2011). Microfinance: Its Impact, Outreach, and Sustainability. World Development, 39(6), 875-881.

Hermes, N., Lensink, R., \& Meesters, A. (2011). Outreach and efficiency of microfinance institutions. World Development, 39(6), 938-948.

Himbara, D. (1994). The failed Africanization of commerce and industry in Kenya. World Development, 22(3), 469-482.

Hofstede, G. (1984). Culture's consequences: International differences in work-related values. sage. 
Ibrahim, G., \& Galt, V. (2011). Explaining ethnic entrepreneurship: an evolutionary economics approach. International Business Review, 20(6), 607-613.

Imai, K. S., Gaiha, R., Thapa, G., Annim, S. K., \& Gupta, A. (2012). Financial Performance of Microfinance Institutions-A Macroeconomic and Institutional Perspective. Research Institute for Economics \& Business Administration, Kobe University, Discussion Paper Series: DP201204.

Karlan, D. (2005). Social Connections and Group Banking. Economic Growth Center, Yale University, Working Papers.

Kent, D., \& Dacin, M. T. (2013). Bankers at the gate: Microfinance and the high cost of borrowed logics. Journal of Business Venturing, 28(6), 759-773.

Khavul, S., Chavez, H., \& Bruton, G. D. (2013). When institutional change outruns the change agent: The contested terrain of entrepreneurial microfinance for those in poverty. Journal of Business Venturing, 28(1), 30-50. doi: 10.1016/j.jbusvent.2012.02.005

Khayesi, J. N. O., George, G., \& Antonakis, J. (2014). Kinship in Entrepreneur Networks: Performance Effects of Resource Assembly in Africa. Entrepreneurship Theory and Practice, 38(6), 13231342.

Kotha, R., \& George, G. (2012). Friends, family, or fools: Entrepreneur experience and its implications for equity distribution and resource mobilization. Journal of Business Venturing, 27(5), 525543.

Kranton, R. E. (1996). Reciprocal exchange: a self-sustaining system. The American Economic Review, $86(4), 830-851$.

Kreiser, P. M., Patel, P. C., \& Fiet, J. O. (2013). The Influence of Changes in Social Capital on Firm-Founding Activities. Entrepreneurship Theory and Practice, 37(3), 539-568.

Kuhn, K. M., \& Galloway, T. L. (2013). With a Little Help From My Competitors: Peer Networking Among Artisan Entrepreneurs. Entrepreneurship Theory and Practice, 39(3), 571-600.

La Ferrara, E. (2002). Self-help Groups and Income Generation in the Informal Settlements of Nairobi. Journal of African Economies, 11(1), 61-89.

Lavoie, D. (1991). The discovery and interpretation of profit opportunities: Culture and the Kirznerian entrepreneur. The Culture of Entrepreneurship, 33-51.

Ledgerwood, J. (1999). Microfinance Handbook. Washington DC: The World Bank. 
Leigh, A. (2006). Trust, Inequality and Ethnic Heterogeneity. Economic Record, 82(258), 268-280. doi: 10.1111/j.1475-4932.2006.00339.x

Light, I., \& Dana, L. P. (2013). Boundaries of social capital in entrepreneurship. Entrepreneurship Theory and Practice, 37(3), 603-624.

Loury, G. C. (1998). Discrimination in the post-civil rights era: beyond market interactions. The Journal of Economic Perspectives, 12(2), 117-126.

Masurel,E., Nijkamp, P., \& Vindigni, G. (2004). Breeding places for ethnic entrepreneurs: a comparative marketing approach. Entrepreneurship \& Regional Development, 16(1), 77-86.

Marris, P. (1971). African businessmen in a dual economy. The Journal of Industrial Economics, 19(3), $231-245$

Marshall, M. G., \& Jaggers, K. (2014). Polity IV Project: Political Regime Characteristics and Transitions, 1800-2009. Dataset Users' Manual. College Park: University of Maryland.

Mauro, P. (1995). Corruption and growth. The Quarterly Journal of Economics, 681-712.

McEvily, B., \& Marcus, A. (2005). Embedded ties and the acquisition of competitive capabilities. Strategic Management Journal, 26(11), 1033-1055.

Michalopoulos, S. (2012). The Origins of Ethnolinguistic Diversity. American Economic Review, 102(4), 1508-1539. doi: 10.1257/aer.102.4.1508

Milgrom, P. R., North, D. C., \& Weingast, B. R. (1990). The role of institutions in the revival of trade: The law merchant, private judges, and the champagne fairs. Economics \& Politics, 2(1), 1-23.

Mishra, V., \& Smyth, R. (2015). Estimating Returns to Schooling in Urban China Using Conventional and Heteroskedasticity-based Instruments. Economic Modelling, 47, 166-173

Mitchell, J. C. (1969). Social networks in urban situations: analyses of personal relationships in Central African towns: Manchester University Press.

Montgomery, J. D. (1991). Social networks and labor-market outcomes: Toward an economic analysis. The American Economic Review, 1408-1418.

Nettle, D. (1998). Explaining global patterns of language diversity. Journal of anthropological archaeology, 17(4), 354-374.

Olivares-Polanco, Francisco. (2005). Commercializing Microfinance and Deepening Outreach? Empirical Evidence from Latin America. Journal of Microfinance, 7(2), 47-69. 
Olsson, O., \& Hibbs, D. A. (2005). Biogeography and long-run economic development. European economic review, 49(4), 909-938.

Platteau, J. P. (1994). Behind the market stage where real societies exist-part I: The role of public and private order institutions. The Journal of Development Studies, 30(3), 533-577.

Quayes, Shakil. (2012). Depth of Outreach and Financial Sustainability of Microfinance Institutions. Applied Economics, 44(25-27), 3421-3433.

Ring, J. K., Peredo, A. M., \& Chrisman, J. J. (2010). Business networks and economic development in rural communities in the United States. Entrepreneurship Theory and Practice, 34(1), 171195.

Robert, B., \& Richerson, P. J. (1985). Culture and the evolutionary process. Chicago: University of Chicago Press.

Robinson, M. (2004). Why the Bank Rakyat Indonesia Has the World's Largest Sustainable Microbanking System." Paper presented at the BRI International Seminar, Bali, Indonesia.

Rosenberg, R., Gonzalez, A., \& Narain, S. (2009). Are Microcredit Interest Rates Excessive? Rochester.

Sanders, J. M., \& Nee, V. (1996). Immigrant Self-Employment: The Family as Social Capital and the Value of Human Capital. American Sociological Review, 61(2), 231-249.

Selznick, P. (1949). TVA and the grass roots. Berkeley: University of California Press.

Sherif, M. (1958). Superordinate Goals in the Reduction of Intergroup Conflict. American Journal of Sociology, 63(4), 349-356. doi: 10.2307/2774135

Shillington, K. (2012). History of Africa. Basingstoke: Palgrave Macmillan.

Slotte-Kock, S., \& Coviello, N. (2010). Entrepreneurship research on network processes: A review and ways forward. Entrepreneurship Theory and Practice, 34(1), 31-57.

Smallbone, D., Kitching, J., \& Athayde, R. (2010). Ethnic diversity, entrepreneurship and competitiveness in a global city. International Small Business Journal, 28(2), 174-190.

Sowell, T. (1981). Ethnic America: a history. New York: Basic Books.

Stam, W., Arzlanian, S., \& Elfring, T. (2014). Social capital of entrepreneurs and small firm performance: A meta-analysis of contextual and methodological moderators. Journal of Business Venturing, 29(1), 152-173.

Stiglitz, J. (1990). Peer Monitoring and Credit Markets. The World Bank Economic Review, 4(3), 351366.

This article is protected by copyright. All rights reserved 
Taylor, C. R. (2000). The Old-Boy Network and the Young-Gun Effect. International Economic Review, 41(4), 871-891.

Wang, C., \& Steiner, B. (2015). Can Ethno-Linguistic Diversity Explain Cross-Country Differences in Social Capital?: A Global Perspective. Economic Record, 91(214), 338-366.

Wilson, K. L., \& Portes, A. (1980). Immigrant enclaves: An analysis of the labor market experiences of Cubans in Miami. American Journal of Sociology, 86(2), 295-319.

Yunus, M. (2003). Banker to the Poor: Micro-Lending and the Battle Against World Poverty. New York: Public Affairs.

Yunus, M. (2008). Turning Beggars Into Entrepreneurs. NPQ: New Perspectives Quarterly, 25(2), 8889. doi: 10.1111/j.1540-5842.2008.00990.x

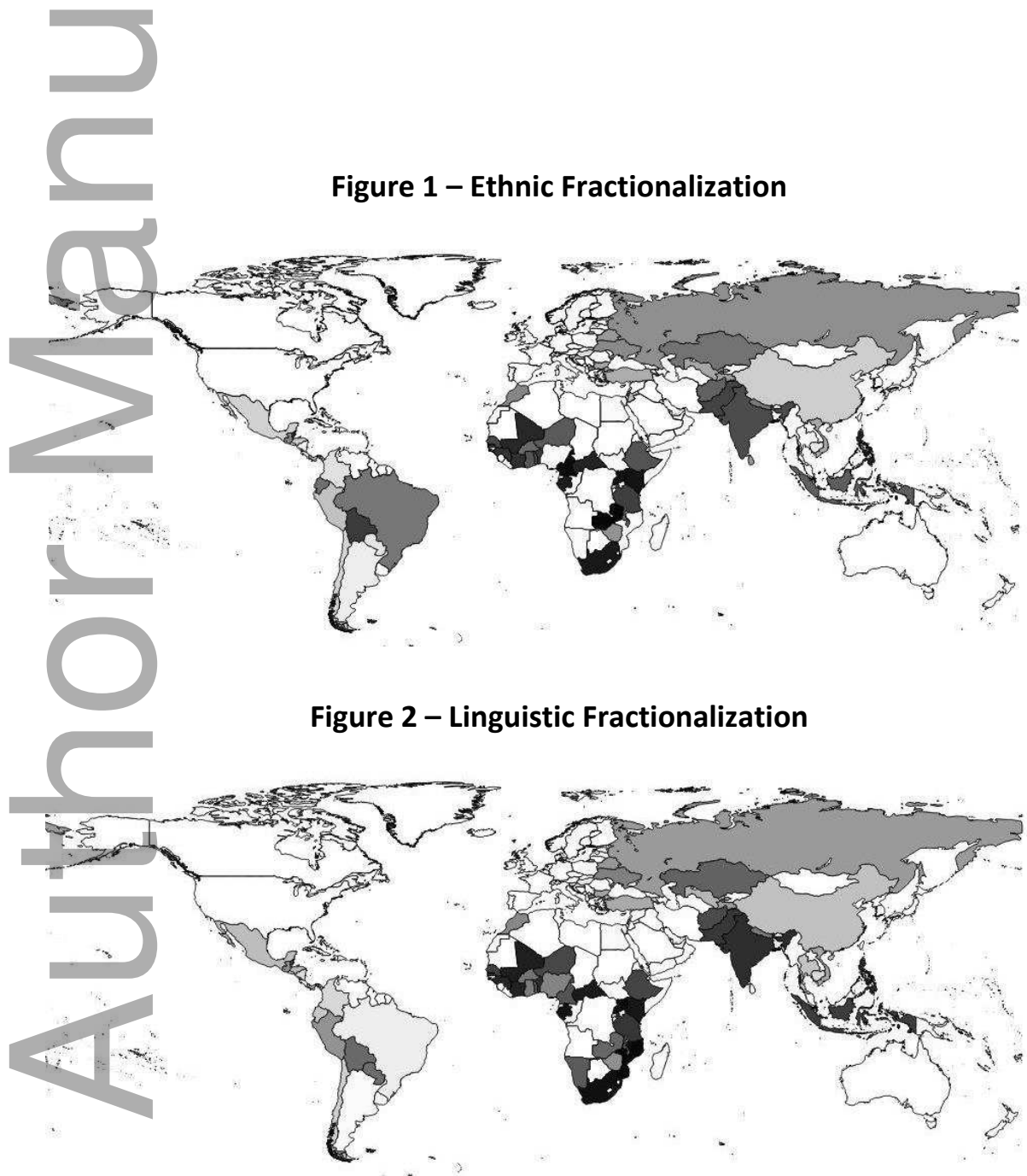

Figure 3 - Religious Fractionalization 


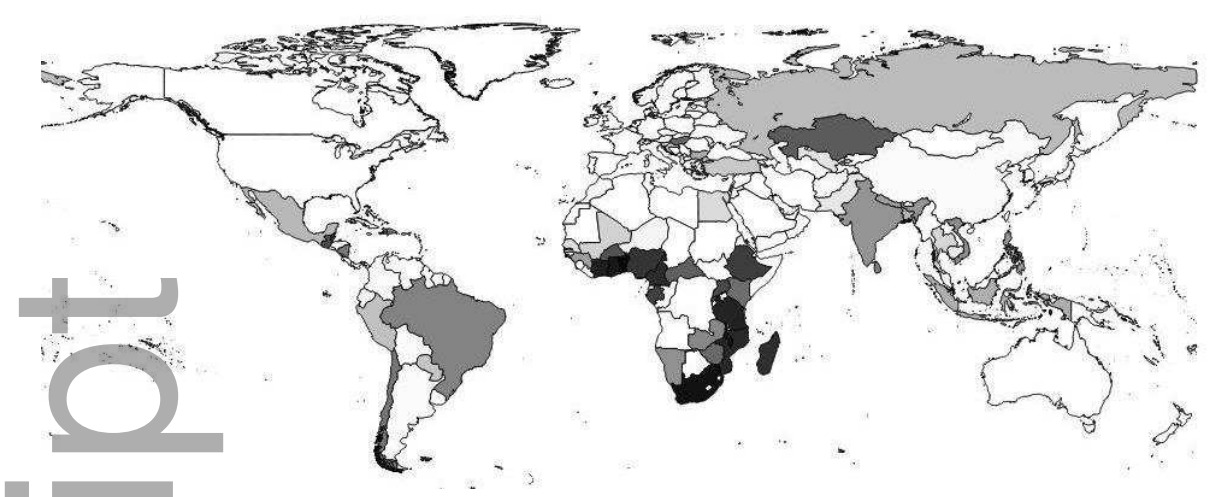

Figure 4-MFI Density

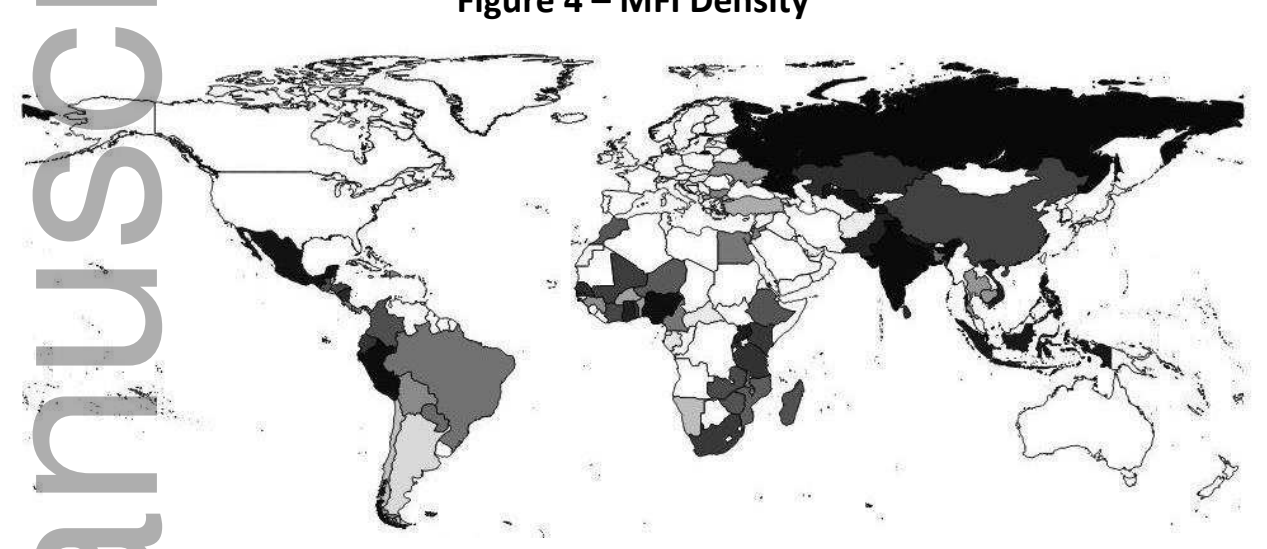

Note: Deeper Share of Grey Represent Higher Fractionalization

Table 1 - The Most and the Least Fractionalized Countries

\begin{tabular}{|c|c|c|c|c|c|}
\hline \multicolumn{3}{|c|}{ Most Fractionalized } & \multicolumn{3}{|c|}{ Least Fractionalized } \\
\hline \multicolumn{6}{|c|}{ Ethnicity } \\
\hline & F Index & MFIs & & F Index & MFIs \\
\hline Zambia & 0.92 & 8 & Bangladesh & 0.02 & 79 \\
\hline Cameroun & 0.90 & 27 & Armenia & 0.04 & 13 \\
\hline Uganda & 0.88 & 28 & Argentina & 0.05 & 18 \\
\hline \multicolumn{6}{|c|}{ Language } \\
\hline & F Index & MFIs & & F Index & MFIs \\
\hline Mozambique & 0.89 & 10 & Haiti & 0.001 & 7 \\
\hline
\end{tabular}

This article is protected by copyright. All rights reserved 


$\begin{array}{lccccc}\text { Uganda } & 0.88 & 28 & \text { Costa Rica } & 0.01 & 17 \\ \text { South Africa } & 0.86 & 17 & \text { Brazil } & 0.01 & 38\end{array}$

\begin{tabular}{lcclcc}
\hline \multicolumn{5}{c}{ Religion } \\
\hline & \multicolumn{5}{c}{} \\
\hline F Index & MFIs & F Index & MFIs \\
\hline Togo & 0.78 & 14 & Niger & 0.01 & 10 \\
Benin & 0.78 & 26 & Armenia & 0.02 & 14 \\
South Africa & 0.76 & 17 & Cambodia & 0.06 & 17 \\
\hline
\end{tabular}

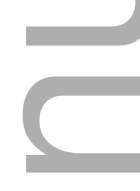

Table 2 - Description and Summary of Variables

\begin{tabular}{llccc}
\hline Variable & \multicolumn{1}{c}{ Description } & Mean & Median & Std \\
& & & & Dev \\
\hline Ethnic Index & Index of Ethnic Fractionalization & 0.47 & 0.28 & 0.28 \\
Linguistic Index & Index of Linguistic Fractionalization & 0.44 & 0.49 & 0.28 \\
Religious Index & Index of Religious Fractionalization & 0.35 & 0.28 & 0.22 \\
Growth & Per Capita GDP Growth & 3.39 & 2.78 & 1.78 \\
Private Credit & Domestic credit to private sector as a share of GDP & 3.52 & 3.65 & 0.71 \\
Remittances & Workers' remittances and compensation & 0.79 & 1.07 & 1.30 \\
& of employees as a share of GDP & & & \\
Population Density & Population/Land Area & 4.34 & 4.27 & 1.28 \\
Unemployment & Percentage of Labour Force Unemployed & 7.33 & 7.00 & 4.37 \\
Institutional Quality & Average of World Bank Governance Indicators & -0.51 & -0.53 & 0.42 \\
Log Age & Age of MFls (Years) & 2.10 & 2.01 & 0.61 \\
Log of Assets & Total MFI assets & 14.56 & 14.53 & 2.09 \\
For-Profit MFls & Dummy=1 if MF is for-profit & 0.36 & 0 & 0.48 \\
Log of Borrowers & Total number of MFI borrowers & 8.24 & 8.29 & 2.04 \\
Log Female Borrowers & Share of Female Borrowers & -0.58 & -0.46 & 0.67
\end{tabular}




\begin{tabular}{llccc} 
Log of Average Loan Size & Average loan size/GDP per capita & -1.27 & -1.33 & 1.39 \\
Log Operational Self & Financial Revenue / (Financial Expense + Impairment & 1.14 & 1.09 & 0.63 \\
Sufficiency & Loss + Operating Expense) & & & \\
Log Return on Assets & (Net Operating Income, less Taxes)/ Assets & -3.53 & -3.38 & 1.09 \\
Log Profit Margin & Net Operating Income/ Financial Revenue & -1.96 & -1.79 & 0.98 \\
Portfolio at Risk & Portfolio at Risk after 90 days & 0.05 & 0.03 & 0.08 \\
Yield & (Yield on Gross Portfolio (nominal) - Inflation Rate)/ & 0.34 & 0.29 & 0.21 \\
& (1+Inflation Rate) & & & \\
Protestant Share & Protestant Share of Population & 4.56 & 1.20 & 8.19 \\
Muslim Share & Muslim Share of Population & 22.85 & 11.30 & 31.45 \\
Catholic Share & Catholic Share of Population & 32.84 & 6.80 & 39.52 \\
Ease of Getting Credit & Ease of Getting Credit Index & 9.35 & 9.41 & 1.69 \\
Business Start-up Ease & Ease of Starting Business Index & 4.33 & 4.39 & 0.19 \\
Business Density & New Businesses Registration per 1000 People & 0.22 & 0.34 & 1.59 \\
Social Networks & Index of Social Networks & 1.27 & 1.48 & 0.57 \\
Discrimination & Index of Discrimination & 4.01 & 4.17 & 1.01 \\
Trust & Index of Generalised Trust & 0.30 & 0.28 & 0.15 \\
Latitude & Log latitude of a country & 2.65 & 2.85 & 1.07 \\
Elevation & Variations in elevation in a country & 0.66 & 0.02 & 1.42 \\
Log duration & Duration of human settlement & 10.62 & 9.75 & 0.93 \\
\hline & & & & \\
\hline
\end{tabular}

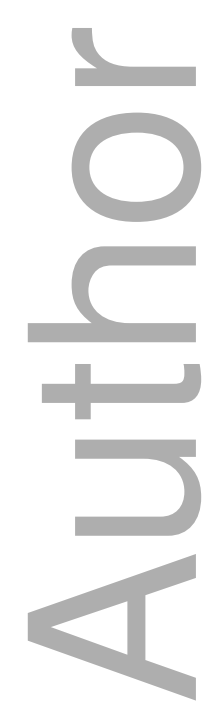

This article is protected by copyright. All rights reserved 
Table 3 - Operational Self-Sufficiency Regressions

\begin{tabular}{|c|c|c|c|c|c|c|c|c|c|c|c|c|}
\hline \multicolumn{13}{|c|}{ Dependent variable: Operational self-sufficiency (OSS) } \\
\hline \multirow[b]{2}{*}{4} & \multicolumn{6}{|c|}{ Panel A: OLS regressions } & \multicolumn{6}{|c|}{ Panel B: IV regressions } \\
\hline & (1) & $(2)$ & (3) & (4) & (5) & (6) & (1) & $(2)$ & (3) & (4) & (5) & (6) \\
\hline \multicolumn{13}{|c|}{ Panel A: second stage regressions } \\
\hline \multirow{3}{*}{ Fractionalization } & $-0.20 * * *$ & $-0.25 * * *$ & $-0.23 * * *$ & $-0.30 * * *$ & $-0.20 * * *$ & 0.45 & $-0.43 * * *$ & $-0.23 * *$ & $-0.62 * * *$ & $-0.44 * * *$ & $-0.53 * * *$ & 0.35 \\
\hline & $(0.05)$ & $(0.06)$ & $(0.05)$ & $(0.06)$ & $(0.08)$ & $(0.30)$ & $(0.11)$ & (0.09) & (0.11) & (0.09) & $(0.14)$ & $(0.52)$ \\
\hline & {$[-0.11]$} & {$[-0.15]$} & {$[-0.14]$} & {$[-0.18]$} & {$[-0.09]$} & [0.19] & {$[-0.25]$} & {$[-0.13]$} & {$[-0.37]$} & {$[-0.26]$} & {$[-0.22]$} & [0.15] \\
\hline \multirow{2}{*}{ Growth } & & 0.07 & & 0.03 & & -0.00 & & 0.06 & & 0.05 & & 0.00 \\
\hline & & $(0.06)$ & & $(0.06)$ & & $(0.08)$ & & $(0.06)$ & & $(0.06)$ & & $(0.08)$ \\
\hline \multirow{2}{*}{ Private credit } & & $0.11 * * *$ & & $0.09 * * *$ & & -0.09 & & $0.10 * * *$ & & $0.09 * * *$ & & -0.08 \\
\hline & & $(0.03)$ & & $(0.03)$ & & $(0.06)$ & & $(0.03)$ & & $(0.03)$ & & $(0.10)$ \\
\hline \multirow[t]{2}{*}{ Remittances } & & $0.04 *$ & & 0.01 & & 0.02 & & 0.04 & & 0.01 & & 0.01 \\
\hline & & $(0.02)$ & & $(0.02)$ & & $(0.02)$ & & $(0.02)$ & & $(0.02)$ & & $(0.03)$ \\
\hline \multirow{2}{*}{ Population density } & & -0.02 & & -0.01 & & -0.01 & & -0.02 & & -0.02 & & -0.00 \\
\hline & & $(0.02)$ & & $(0.02)$ & & $(0.02)$ & & $(0.02)$ & & $(0.02)$ & & $(0.03)$ \\
\hline \multirow{2}{*}{ Unemployment } & & $-0.02 * * *$ & & $-0.01 * * *$ & & 0.00 & & $-0.02 * * *$ & & $-0.01 * * *$ & & -0.00 \\
\hline & & $(0.00)$ & & $(0.00)$ & & $(0.01)$ & & $(0.00)$ & & $(0.00)$ & & $(0.01)$ \\
\hline \multirow{2}{*}{ Institutional quality } & & 0.04 & & 0.06 & & 0.07 & & 0.04 & & 0.07 & & 0.05 \\
\hline & & $(0.07)$ & & $(0.07)$ & & $(0.12)$ & & $(0.07)$ & & $(0.07)$ & & $(0.14)$ \\
\hline \multirow[t]{2}{*}{ Log of age } & & $0.04 *$ & & 0.03 & & 0.02 & & $0.03 *$ & & $0.03 *$ & & 0.02 \\
\hline & & $(0.02)$ & & $(0.02)$ & & $(0.02)$ & & $(0.02)$ & & $(0.02)$ & & $(0.02)$ \\
\hline \multirow[t]{2}{*}{ Log of assets } & & -0.01 & & -0.03 & & -0.03 & & -0.01 & & -0.04 & & -0.03 \\
\hline & & $(0.03)$ & & (0.04) & & $(0.04)$ & & $(0.03)$ & & (0.04) & & $(0.04)$ \\
\hline
\end{tabular}

This article is protected by copyright. All rights reserved 


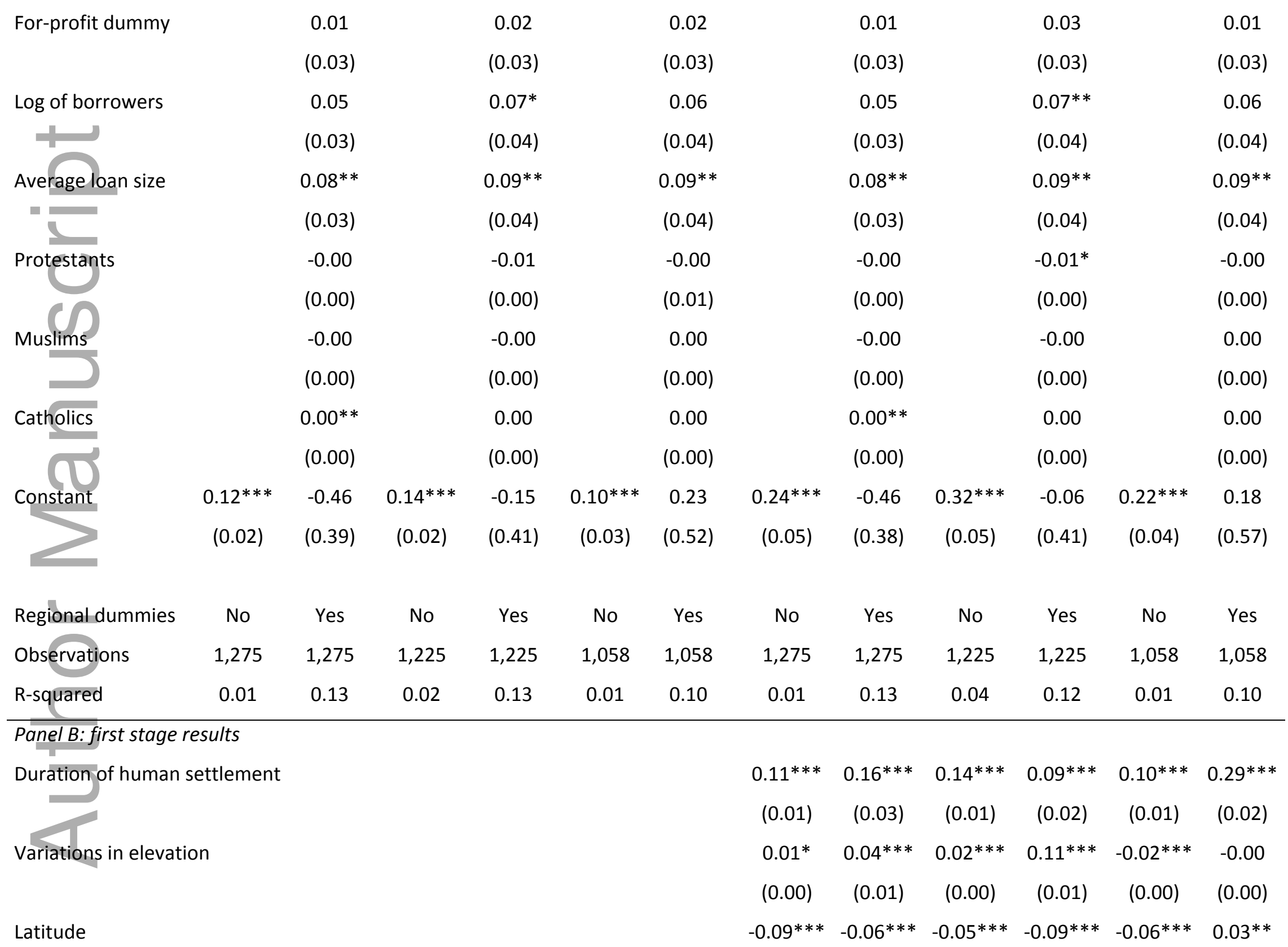

This article is protected by copyright. All rights reserved 


$(0.01) \quad(0.01) \quad(0.01) \quad(0.01) \quad(0.00) \quad(0.01)$

$\begin{array}{lcccccc}\text { R-squared } & 0.22 & 0.32 & 0.22 & 0.72 & 0.31 & 0.80 \\ F \text {-statistic } & 32.24 & 81.25 & 50.27 & 58.10 & 37.19 & 33.55 \\ J \text {-statistic }(P \text {-value) } & 29.73 & 32.31 & 9.64 & 25.88 & 23.83 & 28.45 \\ & 0.179 & 0.334 & 0.075 & 0.055 & 0.102 & 0.098\end{array}$

The measure of fractionalization in Columns 1 and 2 is ethnic fractionalization, Columns 3 and 4 is linguistic fractionalization, and Columns 5 and 6 is religious fractionalization.
OLS results are presented in Panel A while 2 SLS results are presented in Panel B
Robust standard errors adjusted for heteroskedasticity in parentheses
Standardized coefficients in brackets
$\quad{ }^{* * *} p<0.01,{ }^{* *} p<0.05,{ }^{*} p<0.1$

Table 4 - Return on Assets Regressions

\begin{tabular}{|c|c|c|c|c|c|c|c|c|c|c|c|c|}
\hline \multicolumn{13}{|c|}{ Dependent variable: Return on assets (ROA) } \\
\hline & \multicolumn{6}{|c|}{ Panel A: OLS regressions } & \multicolumn{6}{|c|}{ Panel B: IV regressions } \\
\hline & (1) & (2) & (3) & (4) & (5) & (6) & (1) & (2) & (3) & (4) & (5) & (6) \\
\hline \multicolumn{13}{|c|}{ Panel A: second stage regressions } \\
\hline Fractionalization & $\begin{array}{c}-0.05^{* *} \\
(0.02)\end{array}$ & $\begin{array}{c}-0.07 * * * \\
(0.03)\end{array}$ & $\begin{array}{c}-0.08 * * * \\
(0.02)\end{array}$ & $\begin{array}{c}-0.10 * * * \\
(0.03)\end{array}$ & $\begin{array}{c}-0.07^{* *} \\
(0.03)\end{array}$ & $\begin{array}{c}0.08 \\
(0.06)\end{array}$ & $\begin{array}{c}-0.12^{* * *} \\
(0.04)\end{array}$ & $\begin{array}{l}-0.05^{*} \\
(0.03)\end{array}$ & $\begin{array}{c}-0.19 * * * \\
(0.04)\end{array}$ & $\begin{array}{c}-0.14 * * * \\
(0.03)\end{array}$ & $\begin{array}{c}-0.16 * * * \\
(0.05)\end{array}$ & $\begin{array}{c}-0.34 * * * \\
(0.09)\end{array}$ \\
\hline & {$[-0.07]$} & {$[-0.10]$} & {$[-0.11]$} & {$[-0.15]$} & {$[-0.07]$} & {$[0.07]$} & {$[-0.16]$} & {$[-0.07]$} & {$[-0.26]$} & {$[-0.19]$} & {$[-0.15]$} & {$[-0.33]$} \\
\hline Growth & & $0.05^{* *}$ & & $0.04^{*}$ & & 0.03 & & $0.05^{* *}$ & & $0.04^{* *}$ & & 0.02 \\
\hline & & $(0.02)$ & & $(0.02)$ & & $(0.02)$ & & $(0.02)$ & & $(0.02)$ & & $(0.02)$ \\
\hline Private credit & & $0.05^{* * *}$ & & $0.04 * * *$ & & 0.00 & & $0.04 * * *$ & & $0.04 * * *$ & & -0.04 \\
\hline & & $(0.01)$ & & $(0.01)$ & & $(0.02)$ & & $(0.01)$ & & $(0.01)$ & & $(0.03)$ \\
\hline Remittances & & $0.02^{* *}$ & & 0.01 & & 0.01 & & $0.02 * *$ & & 0.01 & & $0.03 *$ \\
\hline
\end{tabular}

This article is protected by copyright. All rights reserved 


\begin{tabular}{|c|c|c|c|c|c|c|c|c|c|c|c|}
\hline & $(0.01)$ & & $(0.01)$ & & $(0.01)$ & & $(0.01)$ & & $(0.01)$ & & $(0.02)$ \\
\hline \multirow[t]{2}{*}{ Population density } & -0.01 & & -0.01 & & -0.01 & & -0.01 & & $-0.01 *$ & & $-0.02 *$ \\
\hline & $(0.01)$ & & $(0.01)$ & & $(0.01)$ & & $(0.01)$ & & $(0.01)$ & & $(0.01)$ \\
\hline \multirow{2}{*}{ Unemployment } & $-0.01 * * *$ & & $-0.01 * * *$ & & -0.00 & & $-0.01 * * *$ & & $-0.01 * * *$ & & 0.00 \\
\hline & $(0.00)$ & & $(0.00)$ & & $(0.00)$ & & $(0.00)$ & & $(0.00)$ & & $(0.00)$ \\
\hline \multirow{4}{*}{ Institutional quality } & -0.04 & & -0.03 & & -0.05 & & -0.04 & & -0.02 & & 0.01 \\
\hline & $(0.05)$ & & $(0.04)$ & & $(0.06)$ & & $(0.05)$ & & $(0.04)$ & & $(0.07)$ \\
\hline & 0.02 & & 0.02 & & 0.02 & & 0.02 & & 0.02 & & 0.03 \\
\hline & $(0.01)$ & & $(0.01)$ & & $(0.02)$ & & $(0.01)$ & & $(0.01)$ & & $(0.02)$ \\
\hline \multirow{2}{*}{ Log of assets } & 0.03 & & 0.03 & & 0.03 & & 0.03 & & 0.02 & & 0.03 \\
\hline & $(0.03)$ & & $(0.04)$ & & $(0.04)$ & & $(0.03)$ & & $(0.04)$ & & $(0.04)$ \\
\hline \multirow{2}{*}{ For-profit dummy } & -0.01 & & -0.01 & & -0.01 & & -0.01 & & -0.00 & & -0.01 \\
\hline & $(0.01)$ & & $(0.01)$ & & $(0.02)$ & & $(0.01)$ & & $(0.01)$ & & $(0.02)$ \\
\hline \multirow{2}{*}{ Log of borrowers } & -0.01 & & -0.00 & & -0.01 & & -0.01 & & -0.00 & & -0.01 \\
\hline & $(0.03)$ & & $(0.03)$ & & $(0.04)$ & & $(0.03)$ & & $(0.03)$ & & $(0.03)$ \\
\hline \multirow{2}{*}{ Average loan size } & -0.00 & & 0.00 & & 0.00 & & -0.00 & & 0.00 & & 0.00 \\
\hline & $(0.02)$ & & $(0.02)$ & & $(0.03)$ & & $(0.02)$ & & $(0.02)$ & & $(0.03)$ \\
\hline \multirow{2}{*}{ Protestants } & -0.00 & & -0.00 & & -0.00 & & -0.00 & & -0.00 & & -0.00 \\
\hline & $(0.00)$ & & $(0.00)$ & & $(0.00)$ & & $(0.00)$ & & $(0.00)$ & & $(0.00)$ \\
\hline \multirow[t]{2}{*}{ Muslims } & -0.00 & & -0.00 & & 0.00 & & -0.00 & & $-0.00 *$ & & 0.00 \\
\hline & $(0.00)$ & & $(0.00)$ & & $(0.00)$ & & $(0.00)$ & & $(0.00)$ & & $(0.00)$ \\
\hline \multirow[t]{2}{*}{ Catholics } & 0.00 & & 0.00 & & 0.00 & & 0.00 & & -0.00 & & -0.00 \\
\hline & $(0.00)$ & & $(0.00)$ & & $(0.00)$ & & $(0.00)$ & & $(0.00)$ & & $(0.00)$ \\
\hline Constant & -0.64 & $0.02 * * *$ & -0.53 & 0.01 & -0.52 & $0.04 * *$ & -0.65 & $0.07 * * *$ & -0.51 & $0.03 *$ & -0.38 \\
\hline
\end{tabular}

This article is protected by copyright. All rights reserved 


$\begin{array}{lllllllllllll}(0.01) & (0.40) & (0.01) & (0.41) & (0.01) & (0.50) & (0.02) & (0.40) & (0.02) & (0.42) & (0.02) & (0.48)\end{array}$

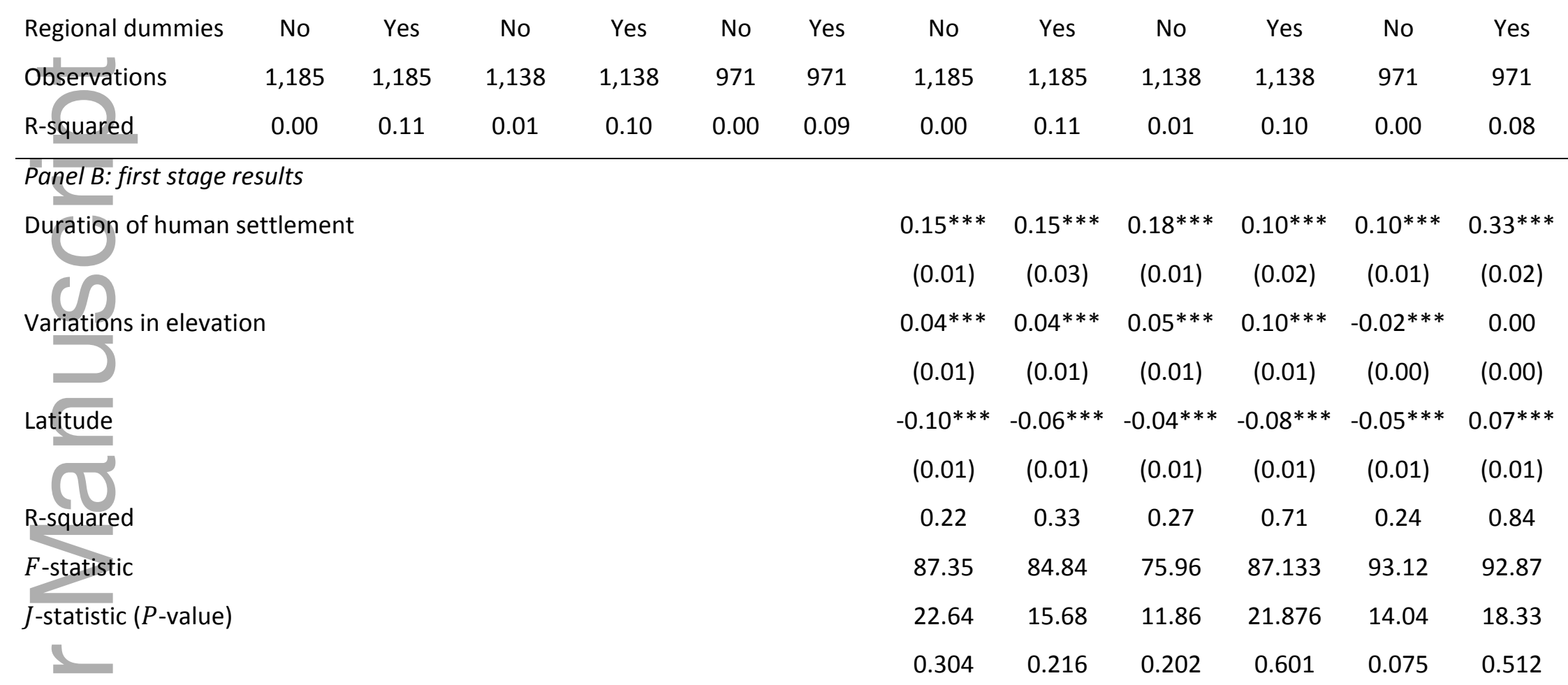

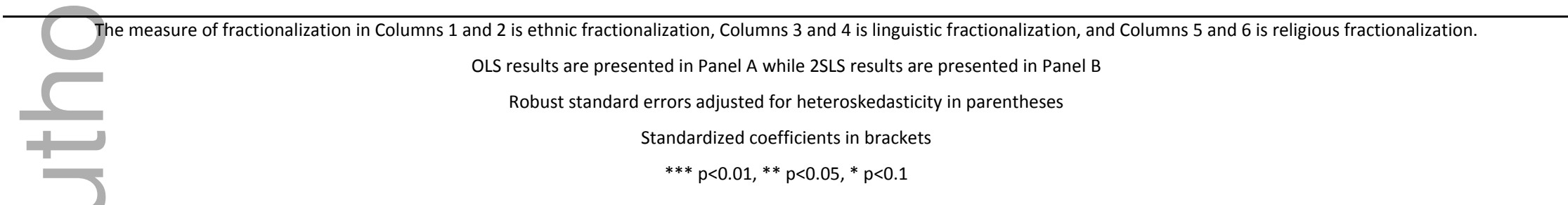

Table 5 - Profit Margin Regressions

Dependent variable: Profit margin

This article is protected by copyright. All rights reserved 


\begin{tabular}{|c|c|c|c|c|c|c|c|c|c|c|c|c|}
\hline & \multicolumn{6}{|c|}{ Panel A: OLS regressions } & \multicolumn{6}{|c|}{ Panel B: IV regressions } \\
\hline & (1) & (2) & (3) & (4) & (5) & (6) & (1) & (2) & (3) & (4) & (5) & (6) \\
\hline \multicolumn{13}{|c|}{ Panel A: second stage regressions } \\
\hline \multirow{3}{*}{ Fractionalization } & $-0.31 * *$ & $-0.31 *$ & -0.14 & $-0.26 *$ & -0.22 & -0.65 & 0.05 & $-0.66 * *$ & 0.36 & $-2.05^{*}$ & -0.03 & $-2.89 *$ \\
\hline & $(0.13)$ & $(0.19)$ & $(0.12)$ & $(0.15)$ & $(0.18)$ & $(0.72)$ & $(0.32)$ & $(0.28)$ & $(0.33)$ & $(1.08)$ & $(0.36)$ & (1.28) \\
\hline & {$[-0.09]$} & {$[-0.09]$} & {$[-0.04]$} & {$[-0.08]$} & {$[-0.05]$} & {$[-0.14]$} & {$[0.01]$} & {$[-0.20]$} & {$[0.11]$} & {$[-0.62]$} & {$[-0.01]$} & {$[-0.62]$} \\
\hline \multirow{2}{*}{ Growth } & & 0.01 & & 0.02 & & -0.10 & & 0.05 & & 0.23 & & 0.19 \\
\hline & & $(0.16)$ & & $(0.14)$ & & $(0.17)$ & & $(0.16)$ & & $(0.24)$ & & $(0.26)$ \\
\hline \multirow{2}{*}{ Private credit } & & -0.12 & & -0.07 & & -0.25 & & -0.05 & & 0.10 & & 0.34 \\
\hline & & $(0.14)$ & & $(0.09)$ & & $(0.17)$ & & (0.14) & & $(0.20)$ & & $(0.42)$ \\
\hline \multirow{2}{*}{ Remittances } & & 0.06 & & 0.02 & & -0.03 & & 0.07 & & 0.08 & & $-0.19 *$ \\
\hline & & $(0.06)$ & & $(0.05)$ & & $(0.07)$ & & $(0.06)$ & & $(0.07)$ & & $(0.12)$ \\
\hline \multirow{2}{*}{ Population density } & & -0.02 & & 0.05 & & 0.10 & & -0.03 & & -0.03 & & $0.22^{* *}$ \\
\hline & & $(0.06)$ & & $(0.05)$ & & $(0.08)$ & & $(0.06)$ & & $(0.07)$ & & $(0.09)$ \\
\hline \multirow{2}{*}{ Unemployment } & & 0.01 & & 0.00 & & 0.02 & & 0.00 & & 0.01 & & -0.05 \\
\hline & & $(0.01)$ & & $(0.01)$ & & $(0.02)$ & & $(0.01)$ & & $(0.01)$ & & $(0.05)$ \\
\hline \multirow{2}{*}{ Institutional quality } & & $0.39 * *$ & & 0.21 & & 0.47 & & $0.32 *$ & & 0.24 & & -0.40 \\
\hline & & (0.19) & & $(0.15)$ & & $(0.33)$ & & (0.19) & & $(0.20)$ & & $(0.60)$ \\
\hline \multirow[t]{2}{*}{ Log of age } & & -0.04 & & -0.01 & & -0.08 & & -0.02 & & 0.07 & & $-0.11 *$ \\
\hline & & $(0.05)$ & & $(0.05)$ & & $(0.06)$ & & $(0.05)$ & & $(0.08)$ & & $(0.07)$ \\
\hline \multirow{2}{*}{ Log of assets } & & 0.02 & & 0.05 & & 0.05 & & 0.01 & & -0.09 & & 0.10 \\
\hline & & $(0.09)$ & & $(0.07)$ & & $(0.10)$ & & $(0.09)$ & & $(0.12)$ & & $(0.10)$ \\
\hline \multirow[t]{2}{*}{ For-profit dummy } & & 0.04 & & 0.09 & & -0.03 & & 0.05 & & $0.31 * *$ & & -0.08 \\
\hline & & $(0.08)$ & & $(0.08)$ & & $(0.08)$ & & $(0.08)$ & & $(0.16)$ & & (0.09) \\
\hline
\end{tabular}

This article is protected by copyright. All rights reserved 


\begin{tabular}{|c|c|c|c|c|c|c|c|c|c|c|c|c|}
\hline \multirow[t]{2}{*}{ Log of borrowers } & & -0.03 & & -0.07 & & -0.06 & & -0.03 & & 0.04 & & -0.10 \\
\hline & & $(0.09)$ & & $(0.07)$ & & $(0.10)$ & & $(0.09)$ & & $(0.11)$ & & $(0.10)$ \\
\hline \multirow{2}{*}{ Average loan size } & & 0.08 & & 0.05 & & 0.10 & & 0.08 & & 0.17 & & 0.04 \\
\hline & & $(0.10)$ & & $(0.08)$ & & $(0.11)$ & & $(0.10)$ & & $(0.11)$ & & $(0.11)$ \\
\hline \multicolumn{2}{|l|}{ Protestants } & 0.01 & & -0.01 & & -0.01 & & 0.00 & & -0.01 & & 0.01 \\
\hline \multicolumn{2}{|l|}{1} & $(0.01)$ & & $(0.01)$ & & $(0.01)$ & & $(0.01)$ & & $(0.01)$ & & $(0.02)$ \\
\hline \multirow{2}{*}{ Muslims } & & $0.00 * *$ & & $0.00 *$ & & 0.00 & & $0.00 *$ & & -0.00 & & -0.01 \\
\hline & & $(0.00)$ & & $(0.00)$ & & $(0.00)$ & & $(0.00)$ & & $(0.00)$ & & $(0.01)$ \\
\hline \multirow[t]{2}{*}{ Catholies } & & -0.00 & & -0.00 & & -0.00 & & -0.00 & & $-0.00^{*}$ & & 0.00 \\
\hline & & $(0.00)$ & & $(0.00)$ & & $(0.00)$ & & $(0.00)$ & & $(0.00)$ & & $(0.00)$ \\
\hline \multirow[t]{2}{*}{ Constant } & $-1.83 * * *$ & -1.01 & $-1.93 * * *$ & $-1.92 * * *$ & $-1.86 * * *$ & -1.26 & $-1.99 * * *$ & -1.13 & $-2.14^{* * *}$ & -0.62 & $-1.95 * * *$ & $-3.83 * *$ \\
\hline & $(0.07)$ & (1.15) & $(0.06)$ & $(0.70)$ & $(0.07)$ & $(1.23)$ & $(0.16)$ & $(1.15)$ & $(0.14)$ & $(1.31)$ & $(0.12)$ & $(1.85)$ \\
\hline Regional dummies & No & Yes & No & Yes & No & Yes & No & Yes & No & Yes & No & Yes \\
\hline Observations & 790 & 790 & 771 & 771 & 644 & 644 & 790 & 790 & 771 & 771 & 644 & 644 \\
\hline R-squared & 0.01 & 0.05 & 0.00 & 0.04 & 0.00 & 0.05 & 0.00 & 0.05 & 0.02 & 0.17 & 0.00 & 0.01 \\
\hline \multicolumn{13}{|c|}{ Panel B: first stage results } \\
\hline \multicolumn{2}{|c|}{ Duration of human settlement } & & & & & & $\begin{array}{c}0.11^{* * *} \\
(0.01)\end{array}$ & $\begin{array}{c}0.23^{* * *} \\
(0.05)\end{array}$ & $\begin{array}{c}0.15^{* * *} \\
(0.01)\end{array}$ & $\begin{array}{c}0.14^{* * *} \\
(0.04)\end{array}$ & $\begin{array}{c}0.08^{* * *} \\
(0.01)\end{array}$ & $\begin{array}{c}0.36^{* * *} \\
(0.02)\end{array}$ \\
\hline \multicolumn{2}{|c|}{ Variations in elevation } & & & & & & $\begin{array}{c}0.02^{* * *} \\
(0.01)\end{array}$ & $\begin{array}{c}0.02 * * * \\
(0.01)\end{array}$ & $\begin{array}{c}0.03 * * * \\
(0.01)\end{array}$ & $\begin{array}{c}0.08^{* * *} \\
(0.01)\end{array}$ & $\begin{array}{c}0.02^{* * *} \\
(0.00)\end{array}$ & $\begin{array}{c}0.01 * * * \\
(0.00)\end{array}$ \\
\hline Latitude & & & & & & & $\begin{array}{c}-0.10 * * * \\
(0.01)\end{array}$ & $\begin{array}{c}-0.05^{* * *} \\
(0.02)\end{array}$ & $\begin{array}{c}-0.03 * * * \\
(0.01)\end{array}$ & $\begin{array}{c}-0.09 * * * \\
(0.02)\end{array}$ & $\begin{array}{c}-0.03^{* *} \\
(0.01)\end{array}$ & $\begin{array}{c}-0.07^{* * *} \\
(0.02)\end{array}$ \\
\hline \multicolumn{2}{|l|}{ R-squared } & & & & & & 0.15 & 0.33 & 0.18 & 0.71 & 0.19 & 0.86 \\
\hline
\end{tabular}

This article is protected by copyright. All rights reserved 


$\begin{array}{lcccccc}F \text {-statistic } & 32.53 & 39.08 & 22.08 & 15.06 & 37.41 & 78.92 \\ J \text {-statistic }(P \text {-value) } & 10.99 & 2.45 & 1.54 & 12.06 & 9.06 & 2.655 \\ & 0.004 & 0.296 & 0.469 & 0.140 & 0.010 & 0.265\end{array}$

The measure of fractionalization in Columns 1 and 2 is ethnic fractionalization, Columns 3 and 4 is linguistic fractionalization, and Columns 5 and 6 is religious fractionalization.

OLS results are presented in Panel A while 2SLS results are presented in Panel B

Robust standard errors adjusted for heteroskedasticity in parentheses

Standardized coefficients in brackets

*** $p<0.01, * * p<0.05, * p<0.1$

Table 6 - Average Loan Size Regressions (Mission Drift)

\begin{tabular}{|c|c|c|c|c|c|c|c|c|c|c|c|c|}
\hline \multicolumn{13}{|c|}{ Dependent variable: Average loan size } \\
\hline & \multicolumn{6}{|c|}{ Panel A: OLS regressions } & \multicolumn{6}{|c|}{ Panel B: IV regressions } \\
\hline & (1) & (2) & (3) & (4) & (5) & (6) & (1) & (2) & (3) & (4) & (5) & (6) \\
\hline \multicolumn{13}{|c|}{ Panel A: second stage regressions } \\
\hline \multirow[t]{2}{*}{ Fractionalization } & $\begin{array}{c}0.65^{* * *} \\
(0.13)\end{array}$ & $\begin{array}{c}0.52 * * * \\
(0.12)\end{array}$ & $\begin{array}{c}0.36 * * * \\
(0.13)\end{array}$ & $\begin{array}{l}0.43^{* *} \\
(0.18)\end{array}$ & $\begin{array}{c}0.86 * * * \\
(0.21)\end{array}$ & $\begin{array}{c}1.53 * * * \\
(0.34)\end{array}$ & $\begin{array}{c}1.65^{* * *} \\
(0.26)\end{array}$ & $\begin{array}{c}2.54 * * * \\
(0.42)\end{array}$ & $\begin{array}{c}1.38 * * * \\
(0.27)\end{array}$ & $\begin{array}{c}0.77^{* * *} \\
(0.24)\end{array}$ & $\begin{array}{c}2.72 * * * \\
(0.34)\end{array}$ & $\begin{array}{c}1.88^{* * *} \\
(0.30)\end{array}$ \\
\hline & {$[0.14]$} & {$[0.11]$} & {$[0.08]$} & [0.09] & {$[0.14]$} & {$[0.25]$} & {$[0.36]$} & {$[0.55]$} & {$[0.30]$} & {$[0.17]$} & {$[0.44]$} & {$[0.30]$} \\
\hline Growth & & $0.52 * * *$ & & $0.52^{* * *}$ & & $0.28 * *$ & & 0.19 & & $0.51^{* * *}$ & & $0.33^{* * *}$ \\
\hline & & $(0.12)$ & & $(0.13)$ & & $(0.13)$ & & $(0.15)$ & & $(0.13)$ & & $(0.12)$ \\
\hline Private credit & & $-0.25^{* * *}$ & & -0.08 & & $-0.39 * * *$ & & $-0.30 * * *$ & & $-0.18 * * *$ & & $-0.38 * * *$ \\
\hline & & $(0.06)$ & & $(0.06)$ & & $(0.10)$ & & $(0.06)$ & & $(0.06)$ & & $(0.08)$ \\
\hline \multirow[t]{2}{*}{ Remittances } & & $0.30 * * *$ & & $0.28 * * *$ & & $0.31 * * *$ & & $0.20 * * *$ & & $0.30 * * *$ & & $0.34 * * *$ \\
\hline & & $(0.04)$ & & $(0.04)$ & & $(0.06)$ & & $(0.04)$ & & $(0.04)$ & & $(0.05)$ \\
\hline Population density & & $-0.38 * * *$ & & $-0.47 * * *$ & & $-0.37 * * *$ & & $-0.25^{* * *}$ & & $-0.55 * * *$ & & $-0.36 * * *$ \\
\hline
\end{tabular}

This article is protected by copyright. All rights reserved 


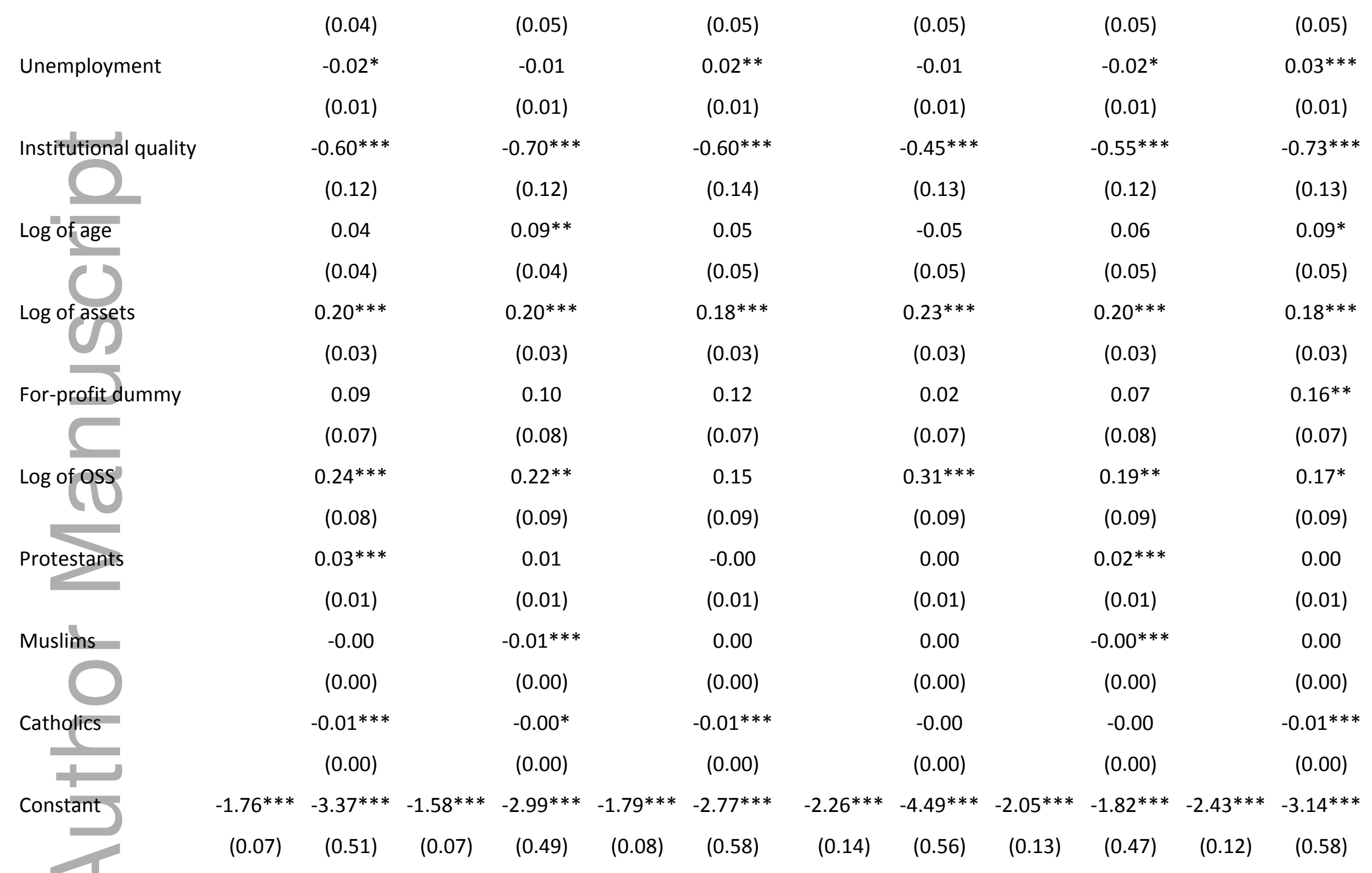

$\begin{array}{lcccccccccccc}\text { Regional dummies } & \text { No } & \text { Yes } & \text { No } & \text { Yes } & \text { No } & \text { Yes } & \text { No } & \text { Yes } & \text { No } & \text { Yes } & \text { No } & \text { Yes } \\ \text { Observations } & 1,275 & 1,275 & 1,225 & 1,225 & 1,058 & 1,058 & 1,275 & 1,275 & 1,225 & 1,225 & 1,058 & 1,058\end{array}$

This article is protected by copyright. All rights reserved 


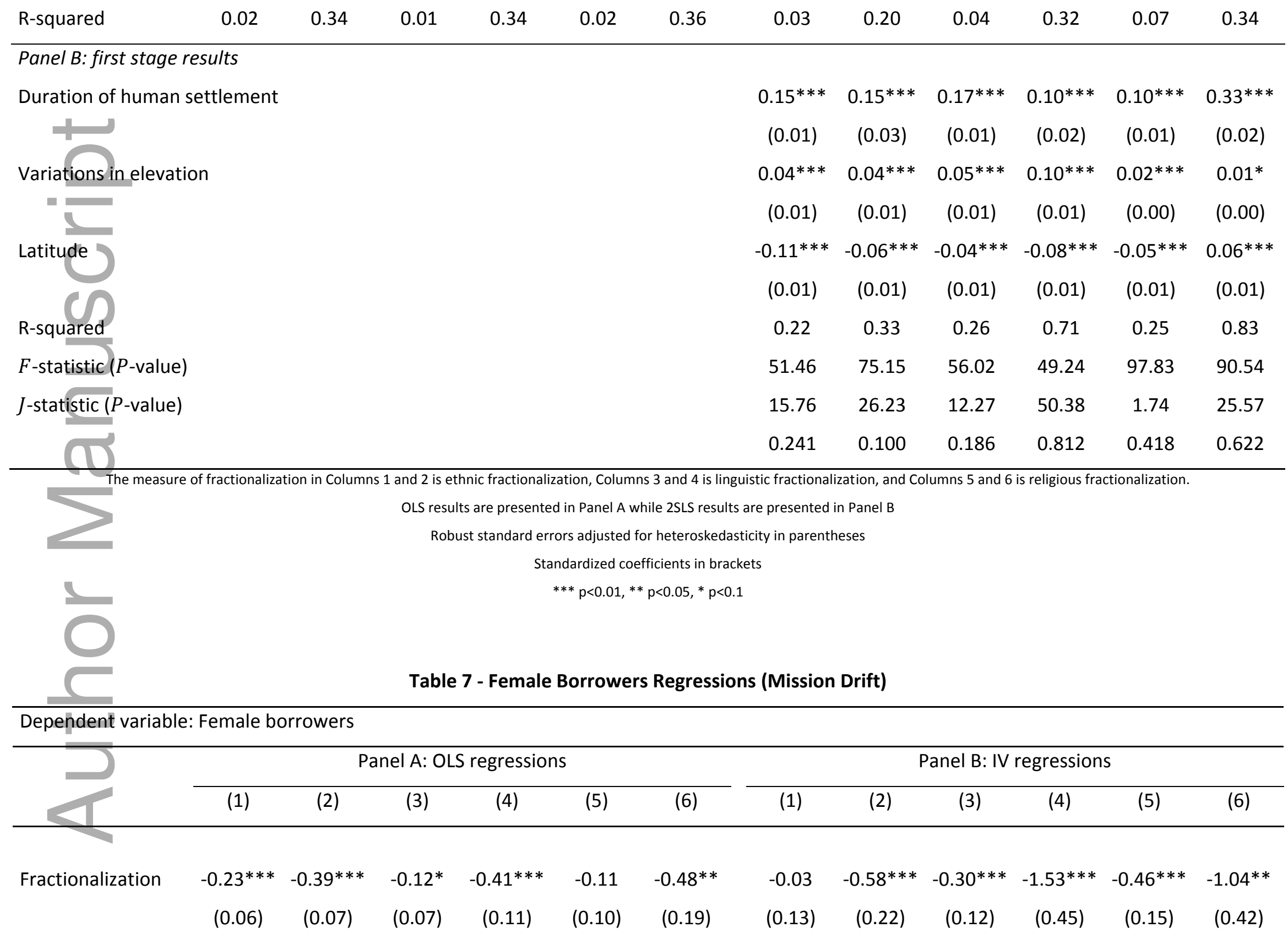

This article is protected by copyright. All rights reserved 


\begin{tabular}{|c|c|c|c|c|c|c|c|c|c|c|c|c|}
\hline & {$[-0.09]$} & {$[-0.16]$} & {$[-0.05]$} & {$[-0.17]$} & {$[-0.03]$} & {$[-0.13]$} & {$[-0.01]$} & {$[-0.23]$} & {$[-0.12]$} & {$[-0.62]$} & {$[-0.13]$} & {$[-0.29]$} \\
\hline \multirow[t]{2}{*}{ Growth } & & $0.24 * * *$ & & $0.26 * * *$ & & $0.35^{* * *}$ & & $0.27 * * *$ & & -0.07 & & $0.28 * * *$ \\
\hline & & $(0.07)$ & & $(0.08)$ & & $(0.08)$ & & $(0.09)$ & & $(0.10)$ & & $(0.08)$ \\
\hline \multirow{2}{*}{ Private credit } & & 0.05 & & $0.07^{*}$ & & $0.17^{* *}$ & & 0.05 & & 0.04 & & 0.06 \\
\hline & & $(0.03)$ & & $(0.04)$ & & $(0.07)$ & & $(0.03)$ & & $(0.04)$ & & $(0.07)$ \\
\hline \multirow{4}{*}{ Population density } & & $0.09 * * *$ & & $0.10 * * *$ & & $0.08^{*}$ & & $0.09 * * *$ & & 0.00 & & $0.17^{* * *}$ \\
\hline & & $(0.03)$ & & $(0.03)$ & & $(0.04)$ & & $(0.03)$ & & $(0.03)$ & & $(0.06)$ \\
\hline & & $0.04 * *$ & & $0.04^{* *}$ & & 0.05 & & 0.03 & & $0.16^{* * *}$ & & 0.05 \\
\hline & & $(0.02)$ & & $(0.02)$ & & $(0.03)$ & & $(0.02)$ & & $(0.04)$ & & $(0.03)$ \\
\hline \multirow{2}{*}{ Unemployment } & & $-0.04 * * *$ & & $-0.04 * * *$ & & $-0.04 * * *$ & & $-0.04 * * *$ & & $-0.04 * * *$ & & $-0.03 * * *$ \\
\hline & & $(0.01)$ & & $(0.01)$ & & $(0.01)$ & & $(0.01)$ & & $(0.01)$ & & $(0.01)$ \\
\hline \multirow{2}{*}{ Institutional quality } & & 0.11 & & $0.13 *$ & & 0.10 & & 0.10 & & 0.04 & & $0.27 * * *$ \\
\hline & & $(0.07)$ & & $(0.07)$ & & $(0.08)$ & & $(0.07)$ & & $(0.07)$ & & $(0.10)$ \\
\hline \multirow{2}{*}{ Log of age } & & $-0.07 * *$ & & $-0.07 * *$ & & $-0.06^{*}$ & & $-0.06 * *$ & & $-0.12 * * *$ & & -0.04 \\
\hline & & $(0.03)$ & & $(0.03)$ & & $(0.04)$ & & $(0.03)$ & & $(0.04)$ & & $(0.04)$ \\
\hline \multirow{2}{*}{ Log of assets } & & -0.01 & & 0.00 & & -0.01 & & -0.01 & & 0.02 & & -0.01 \\
\hline & & $(0.01)$ & & $(0.01)$ & & $(0.01)$ & & $(0.01)$ & & $(0.01)$ & & $(0.01)$ \\
\hline \multirow{2}{*}{ For-profit dummy } & & $-0.13^{* * *}$ & & $-0.11^{* *}$ & & $-0.09 *$ & & $-0.13^{* * *}$ & & $-0.25 * * *$ & & -0.08 \\
\hline & & $(0.04)$ & & $(0.05)$ & & $(0.05)$ & & $(0.04)$ & & $(0.06)$ & & $(0.05)$ \\
\hline \multirow{2}{*}{ Log of OSS } & & $-0.24 * * *$ & & $-0.24 * * *$ & & $-0.15 * * *$ & & $-0.25 * * *$ & & $-0.15 * * *$ & & $-0.20 * * *$ \\
\hline & & $(0.05)$ & & $(0.05)$ & & $(0.05)$ & & $(0.05)$ & & $(0.05)$ & & $(0.05)$ \\
\hline \multirow[t]{2}{*}{ Protestants } & & $0.01 * * *$ & & 0.00 & & $0.01 * *$ & & $0.01 * *$ & & -0.00 & & 0.00 \\
\hline & & $(0.00)$ & & $(0.00)$ & & $(0.00)$ & & $(0.00)$ & & $(0.00)$ & & $(0.00)$ \\
\hline Muslims & & $-0.00 * * *$ & & $-0.00 * * *$ & & $-0.00 * * *$ & & $-0.00 * * *$ & & -0.00 & & 0.00 \\
\hline
\end{tabular}

This article is protected by copyright. All rights reserved 


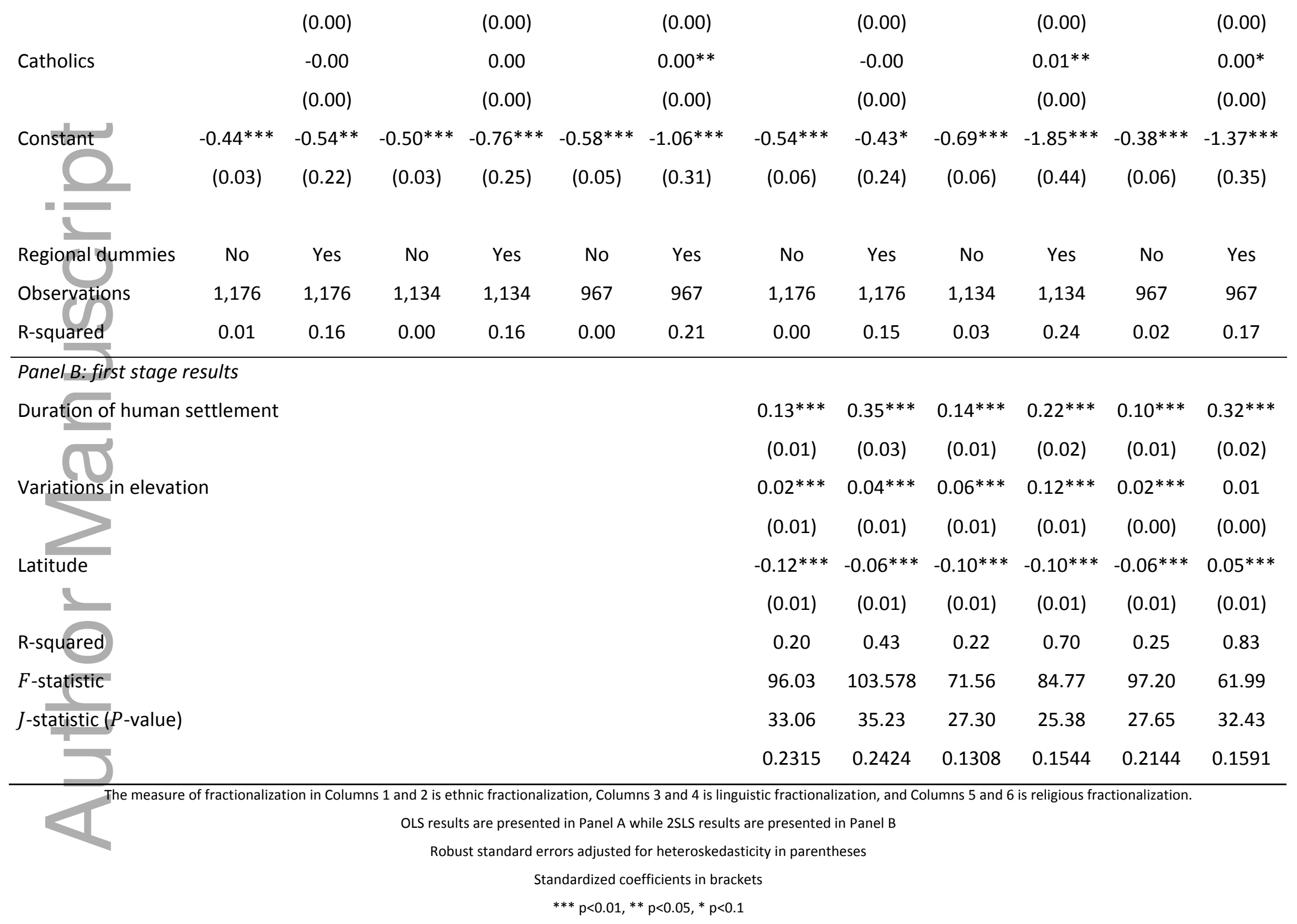

This article is protected by copyright. All rights reserved 
Table 8 - Test of potential channels

\begin{tabular}{|c|c|c|c|c|c|c|c|c|c|}
\hline & \multicolumn{3}{|c|}{ Panel A: Trust included } & \multicolumn{3}{|c|}{ Panel B: Social network included } & \multicolumn{3}{|c|}{ Panel C: Discrimination included } \\
\hline & (1) & (2) & (3) & (1) & $(2)$ & (3) & (1) & $(2)$ & (3) \\
\hline \multicolumn{10}{|c|}{ Dependent variable: Operational self-sufficiency } \\
\hline \multirow[t]{2}{*}{ Fractionalization } & $-0.24 *$ & $-0.43 * * *$ & 0.32 & -0.23 & $-0.37^{* *}$ & 0.43 & -0.30 & -0.40 & 1.74 \\
\hline & $(0.14)$ & $(0.10)$ & $(0.23)$ & $(0.24)$ & $(0.16)$ & $(0.67)$ & $(0.60)$ & $(0.70)$ & $(1.23)$ \\
\hline Observations & 902 & 877 & 771 & 902 & 877 & 771 & 902 & 877 & 771 \\
\hline R-squared & 0.15 & 0.15 & 0.17 & 0.17 & 0.16 & 0.13 & 0.22 & 0.20 & 0.21 \\
\hline \multicolumn{10}{|c|}{ Dependent variable: Return on assets } \\
\hline \multirow[t]{2}{*}{ Fractionalization } & -0.01 & $-0.11 * * *$ & $-0.09 * *$ & -0.10 & $-0.13 * * *$ & $-0.23 * * *$ & 0.10 & -0.12 & -0.17 \\
\hline & $(0.03)$ & $(0.03)$ & $(0.04)$ & $(0.11)$ & $(0.06)$ & $(0.05)$ & $(0.10)$ & $(0.18)$ & $(0.12)$ \\
\hline Observations & 837 & 812 & 708 & 837 & 812 & 708 & 837 & 812 & 708 \\
\hline R-squared & 0.13 & 0.13 & 0.14 & 0.13 & 0.13 & 0.09 & 0.16 & 0.15 & 0.16 \\
\hline \multicolumn{10}{|c|}{ Dependent variable: Profit margin } \\
\hline \multirow[t]{2}{*}{ Fractionalization } & $-0.51 * *$ & $-0.84 * * *$ & $-1.24 * * *$ & -0.89 & $-1.91 * *$ & $-2.13^{* *}$ & 0.08 & $-0.92 * * *$ & 1.76 \\
\hline & $(0.21)$ & $(0.25)$ & $(0.25)$ & $(0.99)$ & $(0.83)$ & $(1.06)$ & $(0.49)$ & $(0.32)$ & $(1.52)$ \\
\hline Observations & 553 & 544 & 465 & 553 & 544 & 465 & 553 & 544 & 465 \\
\hline R-squared & 0.10 & 0.09 & 0.10 & 0.08 & 0.08 & 0.06 & 0.12 & 0.10 & 0.08 \\
\hline \multicolumn{10}{|c|}{ Dependent variable: Average loan size } \\
\hline \multirow[t]{2}{*}{ Fractionalization } & $1.23 * * *$ & $0.58 * *$ & $1.46^{* * *}$ & 0.24 & $0.74^{* *}$ & 0.69 & 0.28 & $0.47 * * *$ & 0.10 \\
\hline & $(0.32)$ & $(0.29)$ & $(0.28)$ & $(0.36)$ & $(0.29)$ & (0.49) & $(0.36)$ & $(0.18)$ & $(0.11)$ \\
\hline Observations & 902 & 877 & 771 & 902 & 877 & 771 & 902 & 877 & 771 \\
\hline
\end{tabular}

This article is protected by copyright. All rights reserved 


\begin{tabular}{|c|c|c|c|c|c|c|c|c|c|}
\hline R-squared & 0.32 & 0.34 & 0.35 & 0.38 & 0.40 & 0.36 & 0.49 & 0.49 & 0.47 \\
\hline \multicolumn{10}{|c|}{ Dependent variable: Female borrowers } \\
\hline \multirow[t]{2}{*}{ Fractionalization } & $-0.24 * * *$ & $-1.39^{* * *}$ & $-0.85 * * *$ & $-0.43^{* *}$ & $-0.57^{* *}$ & -0.37 & -0.23 & -0.20 & -1.48 \\
\hline & $(0.06)$ & $(0.19)$ & $(0.19)$ & $(0.20)$ & $(0.25)$ & $(0.26)$ & $(0.17)$ & $(0.24)$ & (1.19) \\
\hline Observations & 841 & 818 & 715 & 841 & 818 & 715 & 841 & 818 & 715 \\
\hline R-squared & 0.21 & 0.22 & 0.32 & 0.19 & 0.16 & 0.29 & 0.29 & 0.33 & 0.34 \\
\hline
\end{tabular}

The measure of fractionalization in Column 1 is ethnic fractionalization, Column 2 is linguistic fractionalization, and Column 3 is religious fractionalization. Panels A, B and C include trust, social network and discrimination, respectively as an additional control variables.

Robust standard errors adjusted for heteroskedasticity in parentheses

Standardized coefficients in brackets

${ }^{* * *} p<0.01,{ }^{* *} p<0.05, * p<0.1$

This article is protected by copyright. All rights reserved 


\section{University Library}

\section{- M M I N E R VA A gateway to Melbourne's research publications}

Minerva Access is the Institutional Repository of The University of Melbourne

Author/s:

Awaworyi Churchill, S

Title:

Microfinance and Ethnic Diversity

Date:

2017-03-01

Citation:

Awaworyi Churchill, S. (2017). Microfinance and Ethnic Diversity. Economic Record, 93 (300), pp.112-141. https://doi.org/10.1111/1475-4932.12310.

Persistent Link:

http://hdl.handle.net/11343/292228 